Georgetown University Law Center Scholarship @ GEORGETOWN LAW

2022

\title{
On File With: Challenges of Inaccessible References
}

Austin Martin Williams

Georgetown University Law Center, austin.williams@georgetown.edu

This paper can be downloaded free of charge from:

https://scholarship.law.georgetown.edu/facpub/2425

https://ssrn.com/abstract=4014767

Law Library Journal, Vol. 114, No. 2, Pp. 93-129.

This open-access article is brought to you by the Georgetown Law Library. Posted with permission of the author. Follow this and additional works at: https://scholarship.law.georgetown.edu/facpub

Part of the Legal Writing and Research Commons 


\title{
On File With: Challenges of Inaccessible References*
}

\author{
Austin Martin Williams **
}

This article examines how the use of "on file with" citations in student-edited law reviews impacts future research, and it provides a framework for making these materials more accessible. It argues that law libraries are best suited to serve as long-term stewards of these valuable resources.

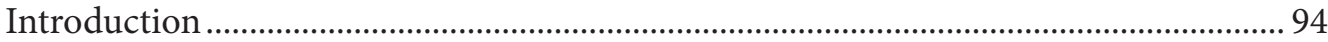

Footnotes and the Use of "On File With" ..................................................................... 96

The Role of Law Review Footnotes......................................................................... 96

The Bluebook and Unpublished Materials................................................................. 98

Use of "On File With" Among Journals .................................................................... 100

General Use Among All Journals ........................................................................ 101

Use Among Top Journals.................................................................................... 103

Foundations for Change ...................................................................................... 110

Open Access Scholarship and Research ................................................................ 110

Tools and Methods for Preservation and Access ..................................................... 112

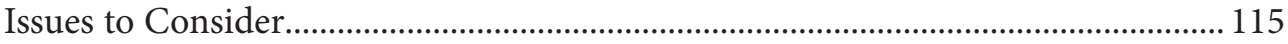

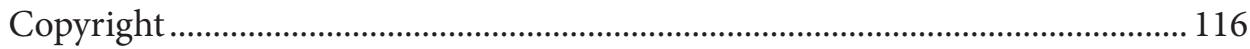

Privacy and Confidentiality ........................................................................... 117

Ever-changing Technology and Long-Term Preservation .................................. 118

Stewardship of Unpublished Materials....................................................................... 119

Reliable Stewardship Ensures Accessibility........................................................ 120

Possible Stewards ............................................................................................... 120

Authors and Original Researchers .................................................................... 121

Journals ..................................................................................................... 122

Research Institutions and Libraries................................................................ 124

Model for Ensuring Long-Term Accessibility ...................................................... 126

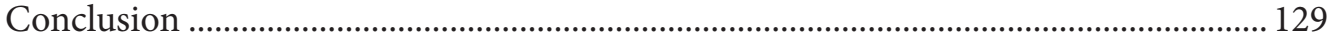

* C Austin Martin Williams, 2022. I wish to thank Michelle Wu and Leah Prescott for their thoughtful comments and suggestions.

** Interim Director of the Law Library, Georgetown University Law Library, Washington, D.C. 


\section{Introduction}

I1 Does reliance on authors for the stewardship of unpublished materials cited in academic articles lessen the writers' creditability and limit the ability of others to build on their work? If "advances in knowledge depend on the open flow of information," should the standard be that all unpublished sources cited in law reviews and journals be made available for review by readers and future researchers?

I2 Several have argued that legal scholarship should be made more widely available because of its potential impact on society. ${ }^{2}$ Over the past decade, the open access movement has encouraged more authors and journals to make legal scholarship freely available through open access journals and institutional repositories. ${ }^{3}$ At the same time, authors, journals, and librarians have taken conscious steps to ensure that sources cited within law journal articles, especially online materials and empirical data, are preserved and cited in ways that provide long-term access to these underlying sources. ${ }^{4}$

$\mathbb{1 3}$ In many ways, the sources cited and relied upon to produce scholarship are as important as the articles themselves. Footnotes and citations provide authority and creditability, allow readers to both challenge the author's assertions and draw their own conclusions, and provide a roadmap for further research exploration. Open scholarship and research benefit not just academics but also nonacademic consumers of legal scholarship, such as attorneys, judges, lawmakers, and the general public.

1. Nat'l Acad. Scis., Nat'l Acad. Eng'g \& Inst. Med., Ensuring the Integrity, Accessibility, and Stewardship of Research Data in the Digital Age 5 (2009), https://doi.org/10.17226/12615 [https://perma.cc/F9ZF-PZJ5].

2. See Richard A. Danner, Applying the Access Principle in Law: The Responsibilities of the Legal Scholar, 35 InT'L J. Legal Info. 355, 357 (2007) ("In law, it can be argued as well that scholars have a particular responsibility to make their work available because of the impact of law on the daily lives of the public, and the influences of legal scholarship on those who make the laws."); James M. Donovan \& Carol A. Watson, Citation Advantage of Open Access Legal Scholarship, 103 Law Libr. J. 553, 558, 2011 Law Libr. J. 35, II 14 ("It has been argued that the need to communicate legal information extends beyond the primary materials to include the articles of secondary scholarly commentary on those laws.").

3. See generally Jessica Litman, The Economics of Open Access Law Publishing, 10 LewIS \& CLARK L. Rev. 779 (2006) (discussing the economics of open access publishing and how it enhances the dissemination of research); Richard A. Danner, Kelly Leong \& Wayne V. Miller, The Durham Statement Two Years Later: Open Access in the Law School Journal Environment, 103 Law Libr. J. 39, 2011 LAw Libr. J. 2 (discussing the current state of the Durham Statement, which called for the open access publication of law school journals); Donovan \& Watson, supra note 2 (making the case that authors have responsibility to make their research available and outlining the case for how open access publishing increases citations to articles); Thomas W. Merrill, The Digital Revolution and the Future of Law Reviews, 99 MARQ. L. Rev. 1101 (2016) (discussing the impact of technology on law review publishing); Kincaid C. Brown, How Many Copies Are Enough Revisited: Open Access Legal Scholarship in the Time of Collection Budget Constraints, 111 LAW Libr. J. 551, 2019 LAW LiBR. J. 19 (studying the availability of law reviews in open access formats).

4. For an overview of link rot and its impact on citing to digital publications, see Susan Lyons, Persistent Identification of Electronic Documents and the Future of Footnotes, 97 Law Libr. J. 681, 2005 Law Libr. J. 42. For an overview on the need to make empirical data available for future researchers, see Benjamin J. Keele \& Michelle Pearse, How Librarians Can Help Improve Law Journal Publishing, 104 LAW Libr. J. 383, 395-98, 2012 LAW Libr. J. 28, III 38-41; see also NAT'L AcAD. Scis., supra note 1, at 70 ("Limitations on the accessibility of data invariably retard, and can even block, the process of verifying the accuracy of those data."). 
I4 While significant steps have been taken to provide for more open research, one class of sources remains mostly unavailable to readers and researchers-unpublished sources that are kept "on file with" the author. ${ }^{5}$ There are many unpublished materials that are readily available, either because they are posted online or are held by institutions such as museums, archives, or libraries that have established sets of practices and procedures for providing access to these materials. However, unpublished materials held by the author carry fewer chances of being available for readers and researchers.

I5 Both Eugene Volokh and Roger Alford have raised the issue of "on file with" citations and their negative impact on legal scholarship. In his 2006 article Law Reviews, the Internet, and Preventing and Correcting Errors, Volokh identified several issues with unpublished sources not being available for readers, and he outlined potential benefits of making these materials more easily accessible. ${ }^{6}$ Volokh argued that placing a source online would "avoid reader errors," in that it would allow future readers to review the underlying source within its full context. ${ }^{7}$ In addition, Volokh believed that making these materials more accessible would hold the author to a higher standard, in that the author would have to be "totally candid in characterizing" research results because "any reader can easily check the sources and cry foul if the author's summary of the source is biased or sloppy." 8 Similar to Volokh, Alford in his 2007 blog post, "On File With Author," called it "absurd" that in "2006 alone, there were over 2,500 articles in the Westlaw JLR library that included this incredibly unhelpful reference." ${ }^{9}$ While Volokh and Alford acknowledged that not every source would be appropriate to be placed online due to possible restrictions related to copyright, privacy, or confidentiality, they both concluded that the majority of these unpublished sources could be placed online, with journals taking on primary responsibility for managing online access. ${ }^{10}$

I6 This article explores the issues and recommendations raised by Volokh and Alford and argues that journals should limit the use of "on file with" the author references and that authors should deposit these materials with reliable stewards that will ensure their long-term preservation and accessibility. ${ }^{11}$ Moreover, journals should expect and require authors to provide either the unpublished source for posting or information on where the source is deposited. In exploring these issues, part 1 of this

5. Rule 17 of The Bluebook provides both examples of and rules for citing to unpublished materials that are commonly referenced in law review articles. The Bluebook: A Uniform System of Citation R. 17.1-17.4, at 169-73 (Columbia L. Rev. Ass'n et al. eds., 21st ed. 2020).

6. Eugene Volokh, Law Reviews, the Internet, and Preventing and Correcting Errors, 116 YALE L.J. Pocket PART 4 (2006), https://www.yalelawjournal.org/forum/law-reviews-the-internet-and-preventing -and-correcting-errors [https://perma.cc/4DCU-RBDV].

7. Id.

8. $I d$.

9. Roger Alford, On File With Author, Opinio JuRIs (Dec. 11, 2007), http://opiniojuris.org/2007/11/12 /on-file-with-author/ [https://perma.cc/W533-5SE7].

10. Volokh, supra note 6; Alford, supra note 9.

11. The term "accessibility" is used in this article as it is described by the National Academy of Sciences, in that accessibility "generally implies public access as well as availability to other researchers upon request. Accessibility does not necessarily imply free access, because providing access to data entails financial costs that must be met." NAT'L ACAD. SCIS., supra note 1, at 26. 
article sets the stage by first looking at footnotes and their role in legal scholarship, the Bluebook's approach to citing unpublished sources, and the use of "on file with" among the top law reviews and journals. Next, part 2 outlines the existing mechanisms to make these sources more accessible and the challenges journals face in doing so. Finally, part 3 argues why accessibility alone is not enough. Instead, journals should deposit these materials with reliable stewards before publication, with law libraries being the best candidates to serve in this role. The goal of this article is to draw awareness to the use of "on file with" the author references and to provide a framework for making these materials more available at the time of an article's publication.

\section{Footnotes and the Use of "On File With"}

17 To understand the importance of making unpublished materials more readily available to all who wish to access them, one must first understand the purpose of footnotes in legal scholarship, the Bluebook's role in setting expectations for authors and journals, and the prevalence of "on file with" citations throughout several major law reviews and journals.

\section{The Role of Law Review Footnotes}

I8 Love them or hate them, footnotes are "an essential ingredient of legal scholarship." 12 Unlike other academic disciplines, most law reviews do not include a bibliography. ${ }^{13}$ Instead, law reviews contain footnotes, which provide bibliographic information on the sources consulted, additional background information on a topic, and substantive commentary that may not fit within the flow of an article's main text. In many instances, a footnote may be more valuable than the sentence it references. ${ }^{14}$

I9 Both the quantity and length of footnotes have been well researched and critiqued over the past several decades. ${ }^{15}$ Most notably, authors lament the need imposed on them by student editors to cite "even the most obvious fact," ${ }^{16}$ which leaves authors

12. Cameron Stracher, Reading, Writing, and Citing: In Praise of Law Reviews, 52 N.Y.L. ScH. L. Rev. 349, 363 (2007) ("Yes, footnotes are awkward; they take additional time to research and write and there are instances in which student editors insist upon them unthinkingly, but footnotes remain the essential ingredient of legal scholarship.").

13. Edd D. Wheeler, The Bottom Lines: Fifty Years of Legal Footnoting in Review, 72 Law LiBr. J. 245, 249 (1979) ("The legal cite must substitute at times for the bibliography, which is used characteristically in much of nonlegal scholarship.").

14. An example of this is a footnote that provides a survey of laws for a given topic. For an example of this type of footnote, see Brian P. Brancato, Blackjack or Bust: Personal Injury Suits on Riverboat Casinos, 19 Tul. MAR. L.J. 133, 135 n.7 (1994) (citing to statutes in six states where riverboat gaming is legal).

15. Much has been written about the disdain with footnotes and over footnoting; see, e.g., Larry A. DiMatteo, Human Capital and the Search for Originality, 16 Berkeley Bus. L.J. 267, 273 (2019) (discussing the very need to footnote and law reviews' "abhorrence for non-sourced statements"); Lori McPherson, Law Review Articles Have Too Many Footnotes, 68 J. Legal Educ. 457, 458 n.1 (2019) (discussing the idea of no original thoughts); Joan Ames Magat, Bottomheavy: Legal Footnotes, 60 J. LeGAL Educ. 65, 82 (2010) (discussing the use of citations for concepts that are common knowledge).

16. Richard A. Wise et al., Do Law Reviews Need Reform: A Survey of Law Professors, Student Editors, 
and student editors with the general rule that "if in doubt, footnote."17 Larry A. DiMatteo argues that the "penchant for complete attribution has led to the proliferation of footnotes"; the way to minimize the number of footnotes, he suggests, is to adopt a new paradigm "where the expert author should be recognized as an intendent source."18 Even if scholars, editors, and the legal community were to agree that law reviews use too many footnotes, ${ }^{19}$ one should not ignore that footnotes provide immense value to authors, readers, and future researchers.

\$10 For authors, footnotes properly attribute sources and establish a work's accuracy and creditability. When citing a source, authors are attributing their findings to the ideas and the work of previous authors and researchers. ${ }^{20}$ This is not to say that there are no original thoughts, ${ }^{21}$ but the footnote's role in conveying attribution does credit those who laid the foundations for an idea. In addition, footnotes provide authors with the all-important validation that they are speaking with both authority and credability. Since American law relies so heavily on precedent, ${ }^{22}$ it makes sense that any assertions made by authors must be "adequately anchored to or differentiated from existing principles and theories." 23 As such, Edd Wheeler summarizes that authors "use the footnote to bolster the credibility of their arguments by demonstrating the full range of their research or by showing what their investigations have in common with the findings of authorities with recognized clout." 24 Thus, this "anxiety of authority", as Michael Bacchus describes it, almost necessitates the need to cite everything to authorize authors' work. ${ }^{25}$ In short, footnotes provide authors with the justification they need to express their new take or interpretation on a topic.

\$11 Even more important than the authority they provide to authors, footnotes are invaluable resources for readers and researchers. They ensure accuracy and serve as essential tools for further research. Unlike other academic disciplines, the majority of legal scholarship is published through student-edited journal ${ }^{26}$ and, as part of the publication process, student editors spend numerous hours combing through footnotes and checking the sources to ensure their accuracy. ${ }^{27}$ Thus, readers can feel confident that, at a minimum, someone has checked to see whether the source exists and, ideally, has

Attorneys, and Judges, 59 Loy. L. Rev. 1, 17 (2013).

17. Wheeler, supra note 13, at 246; see also Stracher, supra note 12, at 361-62.

18. DiMatteo, supra note 15, at 273.

19. See McPherson, supra note 15.

20. Michael Bacchus, Strung Out: Legal Citation, the Bluebook, and the Anxiety of Authority, $151 \mathrm{U}$. PA. L. Rev. 245, 254 (2002).

21. McPherson, supra note 15, at 458 n.1 (2019).

22. Clyde W. Summers, American Labor Law Scholarship-Some Comments, 23 Comp. LAB. L. \& PoL'y J. 801, 801 (2002).

23. Michelle M. Wu, Why Print and Electronic Resources Are Essential to the Academic Law Library, 97 LaW Libr. J. 233, 250, 2005 LAW Libr. J. 14, II 58.

24. Wheeler, supra note 13 , at 249.

25. Bacchus, supra note 20, at 250, 269, 276.

26. See id. at 273; Christian C. Day, The Case for Professionally Edited Law Reviews, 33 OHIO N.U. L. Rev. 563, 563 (2007); Brown, supra note 3, at 559, II 24.

27. Jonathan Mermin, Remaking Law Review, 56 Rutgers L. Rev. 603, 610 (2004). 
checked the substantive accuracy of the author's statements. ${ }^{28}$ While students may or may not fully understand the authors' arguments, ${ }^{29}$ they certainly have reviewed every source by the time articles are published. This, then, allows readers to test authors' assessments and conclusions provided above the line by further examining the underlying information below the line. ${ }^{30}$

I12 In addition to serving as a mechanism to ensure that authors' statements are accurate, footnotes also provide tools for further research on a topic. While some would argue that the number of footnotes, especially those that cover general background on a topic, are excessive and the main culprits for increasingly longer law review articles, ${ }^{31}$ footnotes do provide readers with "pre-packaged research" on a topic. ${ }^{32}$ Joan Ames Magat characterizes footnotes as sources in themselves and explains that "a good, fat footnote is like standing at the library shelf with the book one seeks under one's nose ..." "33 In many ways, footnotes serve as a gateway for future researchers, both educating them on the evolution of a topic and serving as a snapshot in time of what authors considered to be the most "appropriate and convincing authority" on the topic. ${ }^{34}$

I13 While footnotes play an integral role in legal scholarship, it's the Bluebook that shapes and guides their use and sets the expectations for how materials should be cited within the footnotes.

\section{The Bluebook and Unpublished Materials}

I14 The Bluebook holds itself out as the "definitive style guide for legal citation in the United States." ${ }^{35}$ If properly cited, citation forms are "designed to provide the information necessary to lead the reader directly to the specific items cited"; therefore, if a citation format is not contained within the pages of the Bluebook, then authors and editors are encouraged to "provide sufficient information to allow the reader to find the cited material quickly and easily." ${ }^{36}$ While this article does not rehash the benefits and

28. Darby Dickerson, Citation Frustrations-and Solutions, 30 Stetson L. Rev. 477, 481 (2000).

29. See Arthur Austin, Footnote Skulduggery and Other Bad Habits, 44 U. MiA. L. Rev. 1009, 1028-29 (1990); Mermin, supra note 27, at 606.

30. Austin, supra note 29, at 1012.

31. Magat, supra note 15, at 98 (recommending that editors "[f]lag excess in the author's draft. It's tricky business to suggest trimming or deleting material after an author (or her research assistant) has gone to the trouble of composing lists of 'see' or 'see also' works and lengthy but unnecessary background or tangential notes."); DiMatteo, supra note 15, at 300 ("A subset of the legal scholarship critique is that law professors write unnecessarily long and unhelpful law review articles. As noted earlier, articles are too long because they tend to engage in an internal dialogue with other papers, summarizing everything that has ever been said on a given topic by other law professors.").

32. John Doyle, The Law Reviews: Do Their Paths of Glory Lead but to the Grave?, 10 J. App. Prac. \& Process 179, 190 (2009).

33. Magat, supra note 15 , at 71.

34. Day, supra note 26, at 568.

35. Bluebooк, supra note 5, at 1; see also David J. S. Ziff, The Worst System of Citation Except for All the Others, 66 J. Legal Educ. 668, 670 (2017).

36. BluebooK, supra note 5 , at 1 . 
drawbacks of such a voluminous set of standards, many argue that the strict adherence to these rules often increases the number of footnotes in an article. ${ }^{37}$

\$15 Regardless of whether you admire or disdain the detail provided within the Bluebook, it does provide authors, editors, and readers with a consistent set of rules that they can use to decipher the nature of a cited source and locate it or, at minimum, determine the next steps to take to locate the cited source. As the nature of sources evolves, the Bluebook adds and revises citation formats to stay current with sources that authors cite in legal scholarship. ${ }^{38}$

I16 In 1991, the Bluebook's 15th edition added many new citation forms for sources that were not previously covered. ${ }^{39}$ As part of these additions, the Bluebook provided a new rule for several types of commonly cited unpublished materials, including manuscripts, speeches, interviews, and letters. ${ }^{40}$ David E. B. Smith hoped that these additional rules for unpublished materials would remove the worry about citation format and allow editors to "focus on talking the author into sending a copy of that preciously obscure source to the law review so that it really is 'on file." ${ }^{41}$ As this article discusses later, many important documents are still kept "on file with" authors instead of with journals or reliable stewards, such as libraries, museums, or archives.

I17 The recently published 21 st edition of the Bluebook includes citation formats for manuscripts (R. 17.2.1); dissertations and theses (R. 17.2.2); letters, memoranda, and press releases (R. 17.2.3); email correspondence and listserv postings (R. 17.2.4); interviews (R. 17.2.5); speeches and addresses (R. 17.2.6); and forthcoming publications (R. 17.3). ${ }^{42}$ Rule 17.1 also covers sources that are kept on file with journals, university libraries, law libraries of the journal publications, and authors. ${ }^{43}$ Notably absent from Rule 17 is a recommendation for a preferred storage and archival location for these sources. Unlike Rule 18.2.1(d), which outlines that "archiving of internet sources is encouraged, but only when a reliable archival tool is available," 44 Rule 17.2 states simply that authors and editors should provide "if possible, information as to where the work

37. Wise et al., supra note 16, at 17 ("Law reviews slavishly adhere to Bluebook requirements, demanding citations even for the most obvious fact, which stifles creativity and originality and encourages the piling on of footnotes that contain meaningless minutiae.").

38. An example of keeping up with the sources that authors cite is the addition of rules for citing to blogs under Rule 18 in the 18th edition of the Bluebook. The Bluebook: A Uniform System of Citation vi, R. 18.2.4, at 158 (Columbia L. Rev. Ass'n et al. eds., 18th ed. 2005).

39. David E. B. Smith, Just When You Thought It Was Safe to Go Back Into the Bluebook: Notes on the Fifteenth Edition, 67 Chi.-Kent L. Rev. 275, 280 (1991); The Bluebook: A Uniform System of Citation (Columbia L. Rev. Ass'n et al. eds., 15th ed. 1991).

40. Smith, supra note 39 , at 281.

41. Id.

42. Bluebook, supra note 5, R. 17.2.1-17.3, at 169-72. Many of the unpublished sources that are covered under Rule 17 are materials that would not be readily available in print in most law libraries or accessible through general online subscription databases.

43. Id. R. 17.1, at 169 (examples provided include "on file with the Columbia Law Review" for an unpublished manuscript, "on file with the Harvard University Library system" for a thesis, "on file with the Harvard Law School Library" for a memorandum, and "on file with the author" for an email correspondence).

44. Id. R.18.2.1(d), at 177 . 
can be located." ${ }^{45}$ Alford went so far as to recommend that the Bluebook authors should modify then Rule 17.1 to "encourage (or require) law journals to scan and place unpublished documents online." 46 Setting aside several reasons for why a blanket rule may not be feasible for all sources, a stronger recommendation from the Bluebook could inspire a more uniform approach for how these unpublished materials are cited. Thus, journals and authors would be encouraged to take the necessary steps to preserve these sources in ways that would ensure long-term accessibility.

\section{Use of "On File With" Among Journals}

I18 The last aspect of looking at footnotes and their use of the "on file with" reference is to see how prevalent these citations are in journals. In examining this use, I looked at journals overall but focused on four of the top student-edited law journals. ${ }^{47}$ This approach allowed me to take a deeper dive into the diverging practices among these journals and shed further light on the need to adopt more consistent methods throughout legal scholarship. For both the overall and the journal-specific searches, ${ }^{48} \mathrm{I}$ performed a series of searches using the advanced search function on Lexis and Westlaw to search across the footnotes of journals in their respective databases of law reviews and journals. ${ }^{49}$

45. Id. R.17.2, at 169 .

46. Alford, supra note 9.

47. The four journals reviewed were Columbia Law Review, Harvard Law Review, Stanford Law Review, and Yale Law Journal.

48. This article presents the results of the searches in the tables that follow and provides information on the search parameters used for the study in the footnotes. In addition, the results for the searches, including information not conveyed in the tables, is posted online so readers can review the results in more detail, replicate the findings, or perform additional analysis. See Austin Williams, Replication Data For: Search Results for On File With in Law Reviews and Journals, Harv. Dataverse (Mar. 21, 2021), https:// doi.org/10.7910/DVN/3NHNS2.

49. Significant thought went into determining which platform would produce the results most useful for this study. It is well documented that of the three primary vendors for electronic access to law reviews and journals, the coverage in Lexis is less than HeinOnline or Westlaw. See Shannon Furtak, Top 100 Journals Comparison Across Multiple Legal Research Databases, HeinOnline Blog (July 13, 2016), https://home.heinonline.org/blog/2016/07/top-100-journals-comparison-across-multiple-legal-research -databases/ [https://perma.cc/3AAY-FUJA]. The Washington and Lee University School of Law Library uses Westlaw to compile and produce its W\&L Law Journal Rankings. See Ranking Methodology, WASH. \& LEE L.J. RANKINGS, https://managementtools4.wlu.edu/LawJournals/Default3.aspx [https:// perma.cc/3QSN-SLPA]. I chose to use both Lexis and Westlaw because Lexis displays more than 10,000 results, while Westlaw does not return more than 10,000 results. See Shawn G. Nevers \& Julie Graves Krishnaswami, The Shadow Code: Statutory Notes in the United States Code, 112 Law Libr. J. 213, 230-31 n.116, 2020 LAw LiBR. J. 7, II 36, n. 116 (“This brought back 10,000 results, which is Westlaw's maximum, meaning that there were more than 10,000 cases corresponding to this result."). I chose to search across Lexis and Westlaw instead of HeinOnline because both Lexis and Westlaw allow users to limit searches to only the text of the footnotes. 


\section{General Use Among All Journals}

I19 In my initial searches, I focused on documents ${ }^{50}$ published in the databases since January $1,1992^{51}$ that contained "on file with" or one of its two common iterations, "on file in" or "on file at." In Lexis, this search produced a total of 81,381 documents, ${ }^{52}$ while in Westlaw this search produced over 10,000 documents. ${ }^{53} \mathrm{I}$ also filtered the results for this search into two additional time periods: (1) January 1, 1992, to December 31, 2008; and (2) January 1, 2009, to September 19, 2020. Table 1 provides a full breakdown of the results.

Table 1. Initial searches in Lexis and Westlaw across all journals

\begin{tabular}{|l|c|c|c|c|c|c|c|c|}
\hline \multirow{2}{*}{ Dates } & \multicolumn{2}{|c|}{ Any “on file”54 } & \multicolumn{2}{c|}{ “on file” Author55 } & \multicolumn{2}{c|}{ “on file” Journal56 } & \multicolumn{2}{c|}{ “on file” Library57 } \\
\cline { 2 - 11 } & LN & WL & LN & WL & LN & WL & LN & WL \\
\hline $1 / 1 / 92-9 / 19 / 20$ & 81,381 & $10,000+$ & 56,894 & $10,000+$ & 17,996 & $10,000+$ & 4,692 & 4,903 \\
\hline $1 / 1 / 92-12 / 31 / 08$ & 45,529 & $10,000+$ & 30,662 & $10,000+$ & 12,138 & $10,000+$ & 2,373 & 2,526 \\
\hline $1 / 1 / 09-9 / 19 / 20$ & 35,852 & $10,000+$ & 26,232 & $10,000+$ & 5,858 & 5,904 & 2,319 & 2,377 \\
\hline
\end{tabular}

50. This article uses "documents" to describe the results within these databases because the results include all pieces published by a journal, which includes articles, essays, notes, comments, and book reviews.

51. The 15th edition of the Bluebook was published in 1991. See Blueвоoк, supra note 39. To account for its adoption by journals, I restricted my searches to after January 1, 1992.

52. The search parameters used for Lexis were footnote("on file with" or "on file in" or "on file at") across the Lexis Law Reviews \& Journals database. I then limited the results from January 1, 1992, to September 19, 2020.

53. The search parameters used for Westlaw were FOOTNOTE("on file with" or "on file in" or "on file at") \& DA(aft 12-31-1991 \& bef 09-20-2020) across the Westlaw Law Reviews \& Journals content page.

54. The search parameters used for Lexis were footnote("on file with" or "on file in" or "on file at") across the Lexis Law Reviews \& Journals database. I then limited the results for the three time periods. The search parameters used for Westlaw were FOOTNOTE("on file with" or "on file in" or "on file at") \& DA(aft 12-31-1991 \& bef 09-20-2020); FOOTNOTE("on file with" or "on file in" or "on file at") \& DA(aft 12-31-1991 \& bef 01-01-2009); and FOOTNOTE(“on file with" or "on file in" or "on file at") \& DA(aft 12-31-2008 \& bef 09-20-2020) across the Westlaw Law Reviews \& Journals content page.

55. The search parameters used for Lexis were footnote("on file with the author" or "on file with the authors" or "on file with author" or "on file with authors") across the Lexis Law Reviews \& Journals database. I then limited the results for the three time periods. The search parameters used for Westlaw were FOOTNOTE("on file with the author" or "on file with the authors" or "on file with author" or "on file with authors") \& DA(aft 12-31-1991 \& bef 09-20-2020); FOOTNOTE("on file with the author" or "on file with the authors" or "on file with author" or "on file with authors") \& DA(aft 12-31-1991 \& bef 01-01-2009); and FOOTNOTE("on file with the author" or "on file with the authors" or "on file with author" or "on file with authors") \& DA(aft 12-31-2008 \& bef 09-20-2020) across the Westlaw Law Reviews \& Journals content page.

56. The search parameters used for Lexis were footnote((“on file” pre/10 journal) or ("on file” pre/10 review)) across the Lexis Law Reviews \& Journals database. I then limited the results for the three time periods. The search parameters used for Westlaw were FOOTNOTE("on file" $+\mathbf{1 0}$ (journal or review)) \& DA(aft 12-31-1991 \& bef 09-20-2020); FOOTNOTE(“on file" +10 (journal or review)) \& DA(aft 12-31-1991 \& bef 01-01-2009); and FOOTNOTE("on file" +10 (journal or review)) \& DA(aft 12-31-2008 \& bef 09-20-2020) across the Westlaw Law Reviews \& Journals content page.

57. The search parameters used for Lexis were footnote ("on file" pre/10 library) across the Lexis 
I20 I selected January 1, 2009, as a dividing point for two reasons: (1) it was after both Volokh's 2006 and Alford's 2007 calls to reduce the use of "on file with" references in journal articles; and (2) it was after both the May 2008 vote by the Harvard Law School faculty to make their research articles "free and publicly available," 58 as well as the November 2008 meeting between several academic law library directors that resulted in the "Durham Statement on Open Access to Legal Scholarship." ${ }^{9}$

I21 In addition to searching across all documents for any "on file with" references, I ran searches distinguishing where sources were kept-with the author, ${ }^{60}$ a law review or journal, ${ }^{61}$ or a library ${ }^{62}$-for the same time periods. ${ }^{63}$ The results of these searches also appear in table 1. Even with the possibility of overestimating the number of documents that included an "on file with" reference that was held by a journal or a library, ${ }^{64}$ table 1 clearly shows that the practice of the author retaining stewardship over sources is a more common practice than these files being retained by the journal or a library. ${ }^{65}$

Law Reviews \& Journals database. I then limited the results for the three time periods. The search parameters used for Westlaw were FOOTNOTE(“on file" + 10 library) \& DA(aft 12-31-1991 \& bef 09-20-2020); FOOTNOTE("on file" + 10 library) \& DA(aft 12-31-1991 \& bef 01-01-2009); and FOOTNOTE(“on file" +10 library) \& DA(aft 12-31-2008 \& bef 09-20-2020) across the Westlaw Law Reviews \& Journals content page.

58. Athena Y. Jiang, Law School Adopts Open Access for Scholarship, Harv. Crimson (May 7, 2008), https://www.thecrimson.com/article/2008/5/7/law-school-adopts-open-access-for/\#.X-tAbLOdubk.link [https://perma.cc/48QM-U55U]; Open Access and Scholarly Publishing, HARv. L. ScH., https://hls.harvard .edu/library/for-faculty/open-access-and-scholarly-publishing/ [https://perma.cc/PYH7-CXEP].

59. Durham Statement on Open Access to Legal Scholarship, Goodson L. Libr., https://law.duke.edu /lib/durhamstatement [https://perma.cc/45VR-92AZ].

60. For example, see the reference to an interview in footnote 23 that is kept on file with the authors in Jessica Mantel \& Leah Fowler, A Qualitative Study of the Promises and Perils of Medical-Legal Partnerships, 12 Ne. U. L. Rev. 186, 194 n.23 (2020).

61. For example, see the reference to an email in footnote 35 that is kept on file with the Indiana Law Journal in Denise Gilman, To Loose the Bonds: The Deceptive Promise of Freedom from Pretrial Immigration Detention, 92 IND. L.J. 157, 169 n.35 (2016).

62. For example, see the reference to a Technical Conference Smart Grid Interoperability Standard Transcript Document in footnote 10 that is kept on file with the Harvard Law School Library in Joel B. Eisen, Smart Regulation and Federalism for the Smart Grid, 37 Harv. Env't L. Rev. 1, 4 n.10 (2013).

63. I purposely did not include searches for archives or museums because I consider them to be a reliable source for providing these types of materials to researchers.

64. I ran two different searches for journals and libraries. For journals, I looked for either "journal" or "review" within 5 terms and 10 terms of "on file" in both Lexis and Westlaw. For libraries, I looked for "library" within 5 terms and 10 terms of "on file" in both Lexis and Westlaw. In both instances, the searches that looked for "on file" preceding by 5 terms of the desired keyword returned less results than those with "on file" preceding by 10 terms of the desired keyword. For purposes of comparison, I provided the results for within 10 terms in table 1 to be more encompassing, even though the results are likely to include some results that are not applicable. For example, the search for journals returned results where "journal" appeared at the beginning of a sentence immediately after the "on file" reference. See Barbara Hanson Nellermoe, 50 Years of Excellence: A History of the St. Mary's Law Journal, 50 ST. MARY's L.J. 1, 109 n.548 (2019).

65. See supra tbl. 1. 
I22 As this article discusses later on in part $3,{ }^{66}$ allowing the author to maintain stewardship over these sources does raise several concerns in terms of accessibility to future researchers and the long-term preservation of the underlying sources. It is for this reason that when exploring the practices of a smaller subset of journals, I focused on their use of "on file with" references that were kept with the author.

\section{Use Among Top Journals}

\$23 To explore the practices of a smaller subset of journals, I ran similar searches as above, but also looked to see whether the journals had any underlying practices, policies, or resources related to unpublished materials. The four journals that I reviewed were Columbia Law Review, Harvard Law Review, Stanford Law Review, and Yale Law Journal. I chose these four journals because they were the same top four listed by both HeinOnline's ScholarRank's Top 250 Journal ${ }^{67}$ and the W\&L Law Journal Rankings. ${ }^{68}$

$\mathbb{2} 24$ By focusing on these four journals, I was hoping to get a better picture of how often journals used "on file with" references when compared to the number of documents published. In addition, I was hoping that this would shed light on whether journals were following different practices with unpublished materials. For these four journals, I specifically focused on their use of "on file with" references that were kept by the author. Tables 2, 3, and 4 provide the results for searches across the databases of law reviews and journals on Lexis and Westlaw for all documents published within the given time periods, documents with any "on file with" references, and documents with "on file with" the author references.

66. See infra section discussing possible stewards-authors and original researchers.

67. Law Journals-Most Cited, HeInOnLINe, https://heinonline.org/HOL/Index?collection=journals [https://perma.cc/MC6L-LYMS] (after arriving at the Law Journal Library landing page, click on "Most Cited" and then click on "ScholarRank's Top 250 Journals" for the list of top journals. ScholarRank is calculated "based on Bluebook citation analysis across all of the titles available in HeinOnline.").

68. WASh. \& LeE L.J. RANKings, https://managementtools4.wlu.edu/LawJournals/Default.aspx [https://perma.cc/PE53-8MWB]. 
Table 2. All searches restricted from Jan. 1, 1992, to Sept. 19, 2020

\begin{tabular}{|c|c|c|c|c|c|c|c|c|c|c|}
\hline \multirow[t]{2}{*}{ Journals } & \multicolumn{2}{|c|}{ Total Docs ${ }^{69}$} & \multicolumn{2}{|c|}{ Any "on file"70 } & \multicolumn{2}{|c|}{$\begin{array}{c}\% \text { of "on file" w/n } \\
\text { Total Docs"1 }\end{array}$} & \multicolumn{2}{|c|}{ "on file" Author ${ }^{72}$} & \multicolumn{2}{|c|}{$\begin{array}{l}\% \text { of "on file" author } \\
\text { w/n Total Docs }\end{array}$} \\
\hline & LN & WL & LN & WL & $\mathrm{LN}$ & WL & $\mathrm{LN}$ & WL & LN & WL \\
\hline Columbia Law Review & 1,556 & 1,412 & 1,127 & 1,012 & $72.43 \%$ & $71.67 \%$ & 56 & 58 & $3.60 \%$ & $4.11 \%$ \\
\hline Harvard Law Review & 3,910 & 3,583 & 690 & 687 & $17.65 \%$ & $19.17 \%$ & 83 & 77 & $2.12 \%$ & $2.15 \%$ \\
\hline Stanford Law Review & 1,235 & 1,218 & 500 & 521 & $40.49 \%$ & $42.78 \%$ & 338 & 354 & $27.37 \%$ & $29.06 \%$ \\
\hline Yale Law Journal & 2,187 & 1,628 & 732 & 670 & $33.47 \%$ & $41.15 \%$ & 610 & 565 & $27.89 \%$ & $34.71 \%$ \\
\hline
\end{tabular}

69. For each journal, I navigated to the database or content page for that individual journal and pulled all documents published between January 1, 1992, and September 19, 2020.

70. The search parameters used for Lexis were footnote("on file with" or "on file in" or "on file at") across the Lexis Law Reviews \& Journals database for each individual journal. I then limited the results from January 1, 1992, to September 19, 2020. The search parameters used for Westlaw were FOOTNOTE("on file with" or "on file in" or "on file at") \& DA(aft 12-31-1991 \& bef 09-20-2020) across the Westlaw Law Reviews \& Journals content page for each individual journal.

71. I calculated this by taking the number of results with any "on file" reference and dividing it by the total number of results for each journal in the given time period.

72. The search parameters used for Lexis were footnote("on file with the author" or "on file with the authors" or "on file with author" or "on file with authors") across the Lexis Law Reviews \& Journals database for each individual journal. I then limited the results from January 1, 1992, to September 19, 2020. The search parameters used for Westlaw were FOOTNOTE("on file with the author" or "on file with the authors" or "on file with author" or "on file with authors") \& DA(aft 12-31-1991 \& bef 09-20-2020) across the Westlaw Law Reviews \& Journals content page for each individual journal.

73. I calculated this by taking the number of results with any "on file" with the author reference and dividing it by the total number of results for each journal in the given time period. 
Table 3. All searches restricted from Jan 1. 1992 to Dec. 31, 2008

\begin{tabular}{|c|c|c|c|c|c|c|c|c|c|c|}
\hline \multirow[t]{2}{*}{ Journals } & \multicolumn{2}{|c|}{ Total Docs ${ }^{74}$} & \multicolumn{2}{|c|}{ Any “on file"75 } & \multicolumn{2}{|c|}{$\begin{array}{c}\% \text { of "on file" w/n } \\
\text { Total Docs }{ }^{76}\end{array}$} & \multicolumn{2}{|c|}{ “on file" Author77 } & \multicolumn{2}{|c|}{$\begin{array}{c}\% \text { of "on file" author } \\
\text { w/n Total Docs }{ }^{78}\end{array}$} \\
\hline & $\mathrm{LN}$ & $W L$ & LN & WL & LN & WL & $\mathrm{LN}$ & WL & LN & WL \\
\hline Columbia Law Review & 873 & 889 & 536 & 549 & $61.40 \%$ & $61.75 \%$ & 48 & 50 & $5.50 \%$ & $5.62 \%$ \\
\hline Harvard Law Review & 2,142 & 2,184 & 433 & 463 & $20.21 \%$ & $21.20 \%$ & 24 & 31 & $1.12 \%$ & $1.42 \%$ \\
\hline Stanford Law Review & 872 & 860 & 352 & 368 & $40.37 \%$ & $42.79 \%$ & 198 & 210 & $22.71 \%$ & $24.42 \%$ \\
\hline Yale Law Journal & 1,214 & 1,031 & 409 & 411 & $33.69 \%$ & $39.86 \%$ & 315 & 322 & $25.95 \%$ & $31.23 \%$ \\
\hline
\end{tabular}

74. For each journal, I navigated to the database or content page for that individual journal and pulled all documents published between January 1, 1992, and December 31, 2008.

75. The search parameters used for Lexis were footnote("on file with" or "on file in" or "on file at") across the Lexis Law Reviews \& Journals database for each individual journal. I then limited the results from January 1, 1992, to December 31, 2008. The search parameters used for Westlaw were FOOTNOTE(“on file with" or "on file in" or "on file at") \& DA(aft 12-31-1991 \& bef 01-01-2009) across the Westlaw Law Reviews \& Journals content page for each individual journal.

76. I calculated this by taking the number of results with any "on file" reference and dividing it by the total number of results for each journal in the given time period.

77. The search parameters used for Lexis were footnote("on file with the author" or "on file with the authors" or "on file with author" or "on file with authors") across the Lexis Law Reviews \& Journals database for each individual journal. I then limited the results from January 1, 1992, to December 31, 2008. The search parameters used for Westlaw were FOOTNOTE("on file with the author" or "on file with the authors" or "on file with author" or "on file with authors") \& DA(aft 12-31-1991 \& bef 01-01-2009) across the Westlaw Law Reviews \& Journals content page for each individual journal.

78. I calculated this by taking the number of results with any "on file" with the author reference and dividing it by the total number of results for each journal in the given time period. 
Table 4. All searches restricted from Jan. 1, 2009, to Sept. 19, 2020

\begin{tabular}{|c|c|c|c|c|c|c|c|c|c|c|}
\hline \multirow[t]{2}{*}{ Journals } & \multicolumn{2}{|c|}{ Total Docs 79} & \multicolumn{2}{|c|}{ Any "on file"8o } & \multicolumn{2}{|c|}{$\begin{array}{c}\% \text { of "on file" w/n } \\
\text { Total Docs }\end{array}$} & \multicolumn{2}{|c|}{ “on file" Author 82} & \multicolumn{2}{|c|}{$\begin{array}{c}\% \text { of "on file" author } \\
\text { w/n Total Docs }\end{array}$} \\
\hline & $\mathrm{LN}$ & WL & $\mathrm{LN}$ & WL & $\mathrm{LN}$ & WL & LN & WL & LN & $W L$ \\
\hline Columbia Law Review & 683 & 523 & 591 & 463 & $86.53 \%$ & $88.53 \%$ & 8 & 8 & $1.17 \%$ & $1.53 \%$ \\
\hline Harvard Law Review & 1,768 & 1,399 & 257 & 224 & $14.54 \%$ & $16.01 \%$ & 59 & 46 & $3.34 \%$ & $3.29 \%$ \\
\hline Stanford Law Review & 363 & 358 & 148 & 153 & $40.77 \%$ & $42.74 \%$ & 140 & 144 & $38.57 \%$ & $40.22 \%$ \\
\hline Yale Law Journal & 973 & 597 & 323 & 259 & $33.20 \%$ & $43.38 \%$ & 295 & 243 & $30.32 \%$ & $40.70 \%$ \\
\hline
\end{tabular}

I25 There are a number of observations based on the search results. First, there is a clear contrast between Columbia Law Review and Harvard Law Review when compared to Stanford Law Review and Yale Law Journal in regards to the number of documents that included at least one reference that was kept with the author. ${ }^{84}$ Second, while Columbia Law Review was the highest in terms of documents that contained an "on file with" reference, in both number (Lexis-1,127; Westlaw-1,012) and percentage of the documents (Lexis-1,127 out of 1,556, 72.43\%; Westlaw-1,012 out of 1,412, 71.67\%), it was the lowest in terms of the number of documents that contained an "on file with" the author reference (Lexis-56; Westlaw-58), and second lowest in terms of percentage of the total documents (Lexis-56 of 1,556, 3.60\%; Westlaw-58 out of 1,412, $4.11 \%){ }^{85}$ Finally, all but Columbia Law Review saw an increase in the percentage of documents that contained at least one "on file with" the author reference when comparing the first observation period (January 1, 1992, to December 31, 2008) in table 3 to the second observation period (January 1,2009 , to September 19,2020) in table $4 .{ }^{86}$ This is significant because it is counter to what I expected, in that, with more resources available to make these materials accessible through other means, there was instead an increase in allowing authors to keep these materials in their possession. Without deeper

79. For each journal, I navigated to the database or content page for that individual journal and pulled all documents published between January 1, 2009, and September 19, 2020.

80. The search parameters used for Lexis were footnote("on file with" or "on file in" or "on file at") across the Lexis Law Reviews \& Journals database for each individual journal. I then limited the results from January 1, 2009, to September 19, 2020. The search parameters used for Westlaw were FOOTNOTE(“on file with" or "on file in" or "on file at") \& DA(aft 12-31-2008 \& bef 09-20-2020) across the Westlaw Law Reviews \& Journals content page for each individual journal.

81. I calculated this by taking the number of results with any "on file" reference and dividing it by the total number of results for each journal in the given time period.

82. The search parameters used for Lexis were footnote("on file with the author" or "on file with the authors" or "on file with author" or "on file with authors") across the Lexis Law Reviews \& Journals database for each individual journal. I then limited the results from January 1, 2009, to September 19, 2020. The search parameters used for Westlaw were FOOTNOTE("on file with the author" or "on file with the authors" or "on file with author" or "on file with authors") \& DA(aft 12-31-2008 \& bef 09-20-2020) across the Westlaw Law Reviews \& Journals content page for each individual journal.

83. I calculated this by taking the number of results with any "on file" with the author reference and dividing it by the total number of results for each journal in the given time period.

84. See supra tbl. 2.

85. Id.

86. See supra tbls. $3 \& 4$. 
study of the individual uses across all of the documents published since $1992^{87}$ in these four journals or just the documents that contained an "on file with" the author reference, ${ }^{88}$ the initial reasons for the difference between these journals could be the nature of the articles that they published or the policies and resources employed by journals.

I26 After looking at the number of instances between the four journals, I also wanted to determine whether there were specific policies, practices, or resources in place to handle unpublished materials. Yale Law Journal specifically sets out a policy related to unpublished resources in its style guide. ${ }^{89}$ Under S.R. 17: "On File with" in Yale Law Journal's Volume 130 Style Guide, the policy states the following:

We do not store manuscripts. Accordingly, do not cite manuscripts as being "on file with the Yale Law Journal." If a cited manuscript is available in a library or other public location, cite it as being on file at that location; otherwise, cite it as "on file with author(s)."

This clarifies why Yale Law Journal published the most documents since 1992 that contain at least one reference to a source that is maintained by the author. ${ }^{91}$

\27 Harvard Law Review, which had the lowest percentage of documents that contained an "on file with" the author reference since 1992 (Lexis-83 out of 3,910 documents, 2.12\%; Westlaw-77 out of 3,583 documents, $2.15 \%),{ }^{92}$ looks to have taken advantage of a service to retain unpublished materials offered by the Harvard Law School Library's Historical \& Special Collections Department. ${ }^{93}$ When compared to the number of documents published since 1992 that contained an "on file with" reference (Lexis-690, Westlaw-687), ${ }^{94}$ a significant number of documents contained a reference that was kept "on file with" the Harvard Law School Library (Lexis-534; Westlaw-535). ${ }^{95}$ The Documents on File program allows student journals to deposit

87. In Lexis, 8,888 documents were published across the four journals between January 1, 1992, and September 19, 2020. See supra tbl. 2. In Westlaw, 7,841 documents were published across the four journals between January 1, 1992, and September 19, 2020. See id.

88. In Lexis, 1,087 documents were published across the four journals between January 1, 1992, and September 19, 2020, that contained an "on file with" the author reference. See supra tbl. 2. In Westlaw, 1,054 documents were published across the four journals between January 1, 1992, and September 19, 2020, that contained an "on file with" the author reference. See id.

89. Yale L.J., Vol. 130 Style Guide 19, https://www.yalelawjournal.org/files/Volume130StyleGuide _gglowczh.pdf [https://perma.cc/2N5U-CWNM].

90. Id.

91. See supra tbl. 2.

92. Id.

93. See Tools for Student Journals, HARv. L. ScH., https://hls.harvard.edu/dept/dos/student-journals /tools-for-student-journals/ [https://perma.cc/RPA2-5WE6]; Library Services to Journals for Fall 2020, HARv. L. SCH. LiBR., https://guides.library.harvard.edu/law/journalservices20 [https://perma.cc/GCX9 $-34 \mathrm{RN}$ ] (see information under the "Documents on File (Documents, Print)" subheading).

94. See supra tbl. 2. The reference could be "on file with," "on file in," or "on file at."

95. The search parameters used for Lexis were footnote ("on file with" pre/2 "Harvard Law School Library") across the Lexis Law Reviews \& Journals database for Harvard Law Review. I then limited the results from January 1, 1992, to September 19, 2020. The search parameters used for Westlaw were FOOTNOTE(“on file with" + "Harvard Law School Library”) \& DA(aft 12-31-1991 \& bef 09-20-2020) across the Westlaw Law Reviews \& Journals content page for Harvard Law Review. 
"unpublished, difficult to access, or ephemeral sources" that are cited by journals. ${ }^{96}$ After depositing materials under this program, journals are able to note in the explanatory parenthetical that the materials are kept with the library ${ }^{97}$ Of note, the Documents on File program accepts only documents that do not have "access restrictions" or are not available at "other libraries or archival repositories." ${ }^{18}$ Moreover, any documents transferred to the library as part of this program "will be freely accessible to all patrons and subject to HSC Reading Room policies." ${ }^{9}$

I28 While not publicly posted, both Columbia Law Review and Stanford Law Review appear to be following a predetermined set of practices for how they maintain and cite unpublished materials. Columbia Law Review has clearly taken the stance that most unpublished materials will be maintained by the journal. When compared to the number of documents published by the journal since January 1, 1992, that contained at least one reference that was kept "on file with" (Lexis-1,217; Westlaw-1,012), ${ }^{100}$ a significant number of documents contained a reference that was kept "on file with" the law review (Lexis-1,094; Westlaw-990). ${ }^{101}$ On the other hand, Stanford Law Review appears to have taken an approach more similar to Yale Law Journal, where the majority of unpublished materials are maintained by the author, with a few materials maintained by the journal. When compared to the number of documents published by Stanford Law Review since January 1, 1992, that contained at least one reference that was kept "on file with" (Lexis-500; Westlaw-521), ${ }^{102}$ a significant number of documents contained a reference that was kept "on file with" the author (Lexis-338; Westlaw-354), ${ }^{103}$ while far fewer during this time period contained a reference that was kept "on file with" the law review (Lexis-169; Westlaw-181). ${ }^{104}$

I29 These four journals serve as an interesting case study for the different approaches they have taken to citing and maintaining unpublished materials. While Yale Law Journal and Stanford Law Review appear to rely more on the author to maintain stewardship over these materials, Harvard Law Review has relied on its institution's law library to serve in this stewardship role, while Columbia Law Review relies on the

96. Tools for Student Journals, supra note 93.

97. Library Services to Journals for Fall 2020, supra note 93.

98. Id.

99. Id.

100. See supra tbl. 2. The reference could be "on file with," "on file in," or "on file at."

101. The search parameters used for Lexis were footnote("on file with" pre/2 "Columbia Law Review") across the Lexis Law Reviews \& Journals database for Columbia Law Review. I then limited the results from January 1, 1992, to September 19, 2020. The search parameters used for Westlaw were FOOTNOTE(“on file with" + 2 “Columbia Law Review") \& DA(aft 12-31-1991 \& bef 09-20-2020) across the Westlaw Law Reviews \& Journals content page for Columbia Law Review.

102. See supra tbl. 2. The reference could be "on file with," "on file in," or "on file at."

103. $I d$.

104. The search parameters used for Lexis were footnote("on file with" pre/2 "Stanford Law Review") across the Lexis Law Reviews \& Journals database for Stanford Law Review. I then limited the results from January 1, 1992, to September 19, 2020. The search parameters used for Westlaw were FOOTNOTE(“on file with" +2 "Stanford Law Review”) \& DA(aft 12-31-1991 \& bef 09-20-2020) across the Westlaw Law Reviews \& Journals content page for Stanford Law Review. 
journal itself to serve in this role. These four journals provide different examples for how student-edited journals are citing and, ultimately, providing access to the most common unpublished materials appearing within the articles they publish, such as unpublished manuscripts ${ }^{105}$ and emails. ${ }^{106}$ Each journal provides a different example of who ultimately should be responsible for making these unpublished materials accessible to future researchers and who should exercise long-term preservation of these materials. Part 3 of this article will explore each of these types of stewards in further detail to determine which one is best placed to serve in this role. ${ }^{107}$

$\mathbb{1 3 0}$ It should be noted that the results and examples above are simply meant to show that the use of the "on file with" reference is a common practice and, specifically, the use of "on file with" the author is used at such a rate that authors and journals should consider whether it is appropriate for these materials to be preserved by the author. A more complete study would require pulling all of the footnotes for all of the journals and analyzing the total number of citations that are kept "on file with" to determine just how prevalent the use of this parenthetical is, how and when it is most commonly used, and the importance that the unpublished materials have in the authors' overall arguments and conclusions.

105. Unpublished manuscripts are common sources that are cited as "on file with." While most journals cite a version that is available online by providing an SSRN or Perma.cc link, those that are not available online are either retained by the author, held by the journal, or deposited with the library. Stanford Law Review and Yale Law Journal tend to keep these materials on file with the author. For an example from Stanford Law Review, see David Ames et al., Due Process and Mass Adjudication: Crisis and Reform, 72 StAN. L. Rev. 1, 26 n.165 (2020) (unpublished manuscript kept on file with the authors). For an example from Yale Law Journal, see Jonathan S. Gould, Law within Congress, 129 YALE L.J. 1946, 1957 n.30 (2020). Columbia Law Review tends to maintain unpublished manuscripts on file with the journal. For an example, see Daphna Renan, The President's Two Bodies, 120 Colum. L. Rev. 1119, 1150 n.151 (2020) (unpublished manuscript is held on file with the Columbia Law Review). Harvard Law Review deposits most unpublished manuscripts with the Harvard Law School Library. For an example, see Emma Kaufman, The Prisoner Trade, 133 Harv. L. Rev. 1815, 1823 n.19 (2020) (unpublished manuscript is held on file with the Harvard Law School Library).

106. Emails are another example of the different practices followed by these journals. While practice varies some between articles, Harvard Law Review appears to place most emails cited within their articles in their Documents on File program. For an example, see Alexandra Natapoff, Atwater and the Misdemeanor Carceral State, 133 HaRv. L. Rev. F. 147, 147 n.7 (2020) (email from Mac Haas to author that is kept on file with the Harvard Law School Library). Columbia Law Review tends to keep emails on file with the journal. For an example, see Anne Joseph O'Connell, Actings, 120 Colum. L. Rev. 613, 714 n.547 (2020) (email from Alan Morrison, Lerner Family Assoc. Dean, Pub. Interest \& Pub. Serv. Law, Geo. Wash. L. Sch., to author that is held on file with the Columbia Law Review). Yale Law Journal follows the practice that emails are retained by the author. For an example, see Peter Damrosch, Public Rights of First Refusal, 129 YAle L.J. 812, 843 n.147 (2020) (email from Fred Salvucci, former Sec'y of Transp. for Mass., that is held on file with the author). Stanford Law Review follows the same practice as Yale Law Journal and allows emails to remain on file with the author. For an example, see Bijal Shah, Executive (Agency) Administration, 72 Stan. L. Rev. 641, 674 n.157 (email from Cary Coglianese, Prof., Univ. of Pa. L. Sch., to author that is held on file with the author).

107. See infra section discussing possible stewards. 


\section{Foundations for Change}

I31 In the next sections, this article summarizes the steps journals have taken over the past decade to make research more accessible for readers at the time of publication, lays out the mechanisms that authors and journals could employ to make unpublished materials more accessible for future readers, and then outlines the issues that authors and journals must consider before taking steps to make these resources available online.

\section{Open Access Scholarship and Research}

I32 Making materials traditionally kept “on file with" the author more accessible at the time of publication continues the efforts taken over the last 15 years to move toward open access publications. ${ }^{108}$ As the "primary repositories of legal scholarship," ${ }^{109}$ law reviews and journals serve a vital role in communicating the legal information needs of both academics and practitioners. ${ }^{110}$ Since 2008, when both the Harvard Law School faculty voted to make their scholarship available for free online and the directors of several major law libraries met to discuss what would become the "Durham Statement on Open Access to Legal Scholarship," open access publishing of law journals has become the expectation instead of the exception. ${ }^{111}$ There has been such an increase in the number of journals published online since these two events that now many journals are published exclusively online. ${ }^{112}$ The open access movement has also spawned the creation of new online journal formats, such as supplements and companions. ${ }^{113} \mathrm{~A}$ study by Kincaid Brown between 2016 and 2018 found that "more than three-quarters of all law reviews and journal articles were current in open access and half of all law review historical content is available via open access." 114

\33 At the same time that journal publications have become more immediately accessible, librarians and legal scholars have pushed for the sources cited within them to be preserved and made available for future access, review, and critique. The efforts to combat link rot and provide readers with access to an author's underlying empirical research data serve as prime examples of how authors, journals, and libraries have worked together to make the articles themselves more accessible and provided the infrastructure to make the underlying research accessible at the time of publication.

108. See Litman, supra note 3; Danner, Leong \& Miller, supra note 3; Donovan \& Watson, supra note 2; Merrill, supra note 3; Brown, supra note 3.

109. Wise et al., supra note 16 , at 3.

110. DiMatteo, supra note 15 , at 317.

111. See John R. Beatty, Revisiting the Open Access Citation Advantage for Legal Scholarship, 111 LaW Libr. J. 573, 581, 2019 LAW Libr. J. 20, II 25; see also Donovan \& Watson, supra note 2, at 554, II 2.

112. For a list of online-only journals, see the WASH. \& LEE L.J. Rankings, supra note 68 (select "Online Only" in the Format field).

113. Bradley Scott Shannon, Naming Online Law Review Supplements (or Whatever They Are Called), 165 U. Pa. L. Rev. Online 109, 109 (2017).

114. Brown, supra note 3 , at 553, I 6 . 
I34 Ensuring that links and electronic documents referenced in footnotes are accessible has long been a topic of discussion in Law Library Journal. ${ }^{115}$ In 2005, Susan Lyons noted that "[a]s readers we may value the sources more highly than the commentary. An article with dead sources is a dead end."116 Likewise, in 2012, Benjamin Keele and Michelle Pearse stated that broken links are "at best, an annoyance for researchers who must find the resource through another access point. At worst, broken links undermine an article's soundness by removing support for its assertations." 117

\$35 In many ways these dead sources are similar to "on file with" materials that are kept with the author. If a researcher is not able to track down the author or if the author did not retain the materials in a way that they could be shared, then the source is effectively "dead." Some approaches to resolving this issue have been to use web archiving services that preserve a copy of the website for long-term access or citing only stable URLs for documents contained within a platform that is built for long-term preservation. ${ }^{118}$ As this article discusses later, similar approaches could and should be taken for sources cited as "on file with" the author.

\$36 In addition to combating link rot, there has been a push for law journals to adopt similar publication standards as those used by technical and medical journals for articles that rely on empirical research data. As law journal authors have continued to incorporate interdisciplinary approaches to analyzing the law instead of purely doctrinal approaches, ${ }^{119}$ there has been a growing desire to ensure that data are not just preserved but also made available for future users. ${ }^{120}$ Without access to the underlying datasets for empirical projects, future researchers are not able to question or verify the accuracy of the study. ${ }^{121}$

\$37 In one notable instance highlighted by Michele Landis Dauber, the inability to access the underlying data used to support an article made it impossible to subject the underlying evidence of the piece to "different tests"; thus, no one could "dispute" the authors' interpretation of the data. ${ }^{122}$ Not providing access to underlying research data both limits other researchers from subjecting the data to different tests and prevents researchers from determining whether the "original author has made some coding errors or controversial coding judgment calls." ${ }^{23}$ While welcoming the trend toward

115. See generally Lyons, supra note 4 (a study of prevalence of broken links and the need for citing to persistent identifiers of electronic documents); Keele \& Pearse, supra note 4 (as part of a series of recommendations for how librarians can support student journals, the authors dedicate a section to preventing link rot).

116. Lyons, supra note 4 , at 684 , II 10 . Dead sources happen when uniform resource locators (URLs) become "dead" or "broken" links, meaning that the link provided no longer directs the reader to the cited resource, or when the underlying document linked to from the footnote no longer exists online. See id.

117. Keele \& Pearse, supra note 4 , at $391, \mathbb{I} 27$.

118. Id. at 402 , II 47.

119. Id. at 395 , II 38 .

120. Id. at 395-98, III 38-41.

121. NAT'L ACAD. SCIS., supra note 1 , at 70.

122. Michele Landis Dauber, The Big Muddy, 57 Stan. L. Rev. 1899, 1907-09 (2005).

123. Volokh, supra note 6. 
more interdisciplinary scholarship, Dauber believed additional safeguards were needed to ensure empirical work was properly vetted. ${ }^{124}$

\$38 Authors, journals, and institutions have taken steps to make research data more accessible through online preservation tools. Harvard University's Dataverse is a prime example of a service that authors and journals can use to store datasets for preservation and access. ${ }^{125}$ In addition, authors and journals can upload datasets to their institutions' online repositories for the same purposes. ${ }^{126}$ One journal in particular, New York University Law Review, requires authors to provide datasets for publication on its website to ensure "transparency and reproducibility in papers that use methodologies typically employed by the social sciences." 127

I39 As exhibited above, if a footnote fails to provide a means to access its sources, then it fails also to meet its "basic function," which is "to allow 'the interested reader to test the conclusions of the writer and to verify the source of a challengeable statement."'128 As the next section lays out, the technology and infrastructure are now in place to make that happen for many unpublished materials.

\section{Tools and Methods for Preservation and Access}

I40 Since Volokh's and Alford's calls for online posting of "on file with" materials, ${ }^{129}$ significant tools and methods have been developed to support open access scholarship. These same tools could be used to preserve these materials in an online format and make them widely available to readers and researchers. As this article outlines below, it's not enough that the technology is in place to make this happen. Authors and journals have to take deliberate steps to make these documents available prior to the final publication of the articles.

$\mathbb{I} 41$ Online repositories provide stable, easy-to-use platforms that could easily support hosting "on file with" materials. In 2011, 30 law schools had institutional repositories. ${ }^{130}$ At the time of writing this article, 81 law schools maintained institutional repositories through the bepress Digital Commons platform. ${ }^{131}$ Platforms like bepress

124. Dauber, supra note 122, at 1913-14.

125. Harv. Dataverse, https://dataverse.harvard.edu/ [https://perma.cc/Q6G5-T8YW]. The support page states that "Open to those outside of the Harvard Community, Dataverse allows researchers to set some restrictions on access to the data, terms of use, and provides a Digital Object Identifier (DOI), which is a stable and persistent identifier that can be used in citations to direct readers and future researchers to the data set." Dataverse Support, HARv. DATAverse, https://support.dataverse.harvard.edu/ [https:// perma.cc/L8YX-F9MF]. For a discussion on Dataverse and similar services, see Keele \& Pearse, supra note 4, at 396-97, III 40-41.

126. Keele \& Pearse, supra note 4, at 392-93, II 30.

127. Submissions, N.Y.U. L. REv., https://www.nyulawreview.org/submissions/ [https://perma.cc/NL X2-E9NE] (unless an exception is made or the data are already published in the paper).

128. Austin, supra note 29, at 1012 (quoting Carolyn O. Frost, The Use of Citations in Literary Research: A Preliminary Classification of Citation Functions, 49 Libr. Q. 399, 399 (1979)).

129. See Volokh, supra note 6; Alford, supra note 9.

130. Kincaid C. Brown, Law School Institutional Repositories: A Survey, 25 Trends Interactive 21, 21 (2015).

131. Law Schools, BEPREss, https://bepress.com/categories_wdc/law-schools/ [https://perma.cc/N5 
or DSpace allow users to upload materials to an online repository that assigns a unique identifier, reducing the chances of broken links or link rot compared to posting these materials on a standard website. ${ }^{132}$ Because so many journals now publish on these platforms, authors could post "on file with" materials right along with their articles. Platforms similar to Harvard's Dataverse can host "on file with" materials separate from the journal's publication platform. Dataverse's use of digital object identifiers (DOI) ${ }^{133}$ further reduces the likelihood of broken links and increases the odds that documents will be preserved online indefinitely. In addition, platforms for posting working papers and preprints like SSRN or LawArXiv also allow authors to post their own working papers and unpublished manuscripts, which they can then cite back to using a DOI or a persistent URL. ${ }^{134}$

I42 In addition to online repositories, web archiving tools make it easy for authors, journals, and libraries to capture online content and preserve it for long-term use. Perma.cc in particular is a popular tool that many in the law field have embraced as a way to capture and thus preserve webpages and other online content. ${ }^{135}$ While commonly used for archiving webpages, Perma.cc can be employed in combination with online repositories. For example, an article author could cite the repository page for the cited document and also provide a Perma.cc link that includes a PDF version of the document. ${ }^{136}$ Posting the unpublished materials to a stable online platform, providing

9B-HL4Y] (AccessLex and New England Law Library Consortium appear on the list but are not counted as part of the 81 law schools identified).

132. Brown, supra note 3, at 562, II 29; Keele \& Pearse, supra note 4, at 392-93, II 30.

133. For an overview of DOIs, see Benjamin J. Keele, A Primer on Digital Object Identifiers for Law Librarians, 20 Trends L. Libr. Mgmt. \& Tech. 35 (2010).

134. See SSRN, https://www.ssrn.com/index.cfm/en/ [https://perma.cc/HK5E-L7FX]; LAwArXIv, https://osf.io/preprints/lawarxiv [https://perma.cc/NN5Q-C5XT]; About, LawArXIv Info, http:// lawarxiv.info/about [https://perma.cc/KN62-QCSD]. During the original drafting of this article in the fall of 2020, LawArXiv was still accepting author submissions. As reported by Gary Price on InfoDocket, LawArXiv stopped accepting submissions at the beginning of 2021. Gary Price, Preprints: Statement on Why LawArXiv Is No Longer Accepting Submissions, InfoDocket (Feb. 2, 2021), https://www.infodocket. com/2021/02/02/preprints-statement-on-why-lawarxiv-repository-is-no-longer-accepting-submissions/ [https://perma.cc/DU5Q-TERR]. I chose to continue to use LawArXiv as an example for this article for two reasons: (1) the possibility that it could be relaunched in the future; and (2) it provides an example of a nonprofit alternative to SSRN.

135. About Perma.cc, PeRMA.Cc, https://perma.cc/about [https://perma.cc/XH85-D5TS].

136. Perma.cc allows users to upload an image or a PDF file if the standard capture method does not work. Perma Records \& Links, Perma.cC, https://perma.cc/docs/perma-link-creation [https:// perma.cc/E85D-JBTE]. This allows authors to upload the unpublished resource that they are citing to in their articles. An example of this is found in Kate Klonick, The Facebook Oversight Board: Creating an Independent Institution to Adjudicate Online Free Expression, 129 YALE L.J. 2418, 2430 n.33 (2020) (the author cites to Automation in Moderation by Hannah Bloch-Wehba and provides both the SSRN link, https://ssrn.com/abstract=3521619, and a Perma.cc link, https://perma.cc/66NP-WE6Y, that provides the PDF of the document that was housed on SSRN). Simply providing a Perma.cc link to the SSRN page alone will preserve only the SSRN record, not the document itself. An example of this appears in Michael Coenen, Rules against Rulification, 124 YALE L.J. 644, $655 \mathrm{n} .28$ (2014) (the author cites to The Rule of Law as a Law of Law by Steven G. Calabresi \& Gary Lawson and provides both the SSRN link, http://ssrn.com/ abstract=2412025, and a Perma.cc link, http://perma.cc/B7U5-TGVW, but the Perma.cc link captures only 
the DOI or a persistent URL to the page, and then also providing a Perma.cc link to the PDF makes it more likely that these materials will be accessible online in some form. ${ }^{137}$

I43 For materials that are sensitive in nature, the underlying methods used to make controlled digital lending possible could be an option for making these materials more accessible without the worries that the materials could be altered or duplicated. ${ }^{138}$ Allowing researchers to gain access to and view an encrypted, protected document could provide the means necessary to review and critique the original author's work without posting the materials for large-scale, simultaneous use. ${ }^{139}$ Using this method, authors or journals would need to ensure that a copy is digitized and retained in a format that could be shared with future researchers.

I44 By uploading materials prior to publication, authors would be able to cite documents in their journal articles, which would allow readers to quickly access the files when reviewing the articles. ${ }^{140}$ Posting materials prior to publication provides many benefits, most notably a link that would be available in the published article. Not only would this make it easier for researchers to find original sources when reviewing the article, but it also means the link would show up in more places as legal research databases post the article.

I45 While posting the materials prior to publication is ideal, other options would serve a similar purpose. Simply creating the landing page or a record on a platform like bepress or Dataverse would allow the author to provide the link in the article to where the materials will eventually reside after publication. The value of a platform like Dataverse is not just that it serves as a preservation tool and a way to provide stable and reliable access, but it also allows uploaders to restrict access to the data. ${ }^{141} \mathrm{~A}$ researcher

the SSRN page).

137. While not an unpublished document, for an example of a Perma.cc link that captures the PDF version of an article hosted on a bepress Digital Commons platform, see Austin Martin Williams, Researching Georgia Law (2015 Edition), 31 GA. ST. U. L. Rev. 741 (2015), https://readingroom.law.gsu .edu/gsulr/vol31/iss4/4 [https://perma.cc/7373-9V3N] (the Perma.cc link provided archives the entire article that was opened after clicking on the "Download" button on the article's repository landing page). The bepress Legal Repository is marketed as a system that can host, among other things, working papers, preprints, and other unpublished materials. See FAQ for Authors, BEPREss Legal RePository, https://law .bepress.com/faq-authors.html [https://perma.cc/GHJ3-HR3P]. Depending on how the repository is structured and administered, this platform does provide authors and journals with opportunities for posting unpublished materials that can be archived in multiple ways.

138. See generally David R. Hansen \& Kyle K. Courtney, A White Paper on Controlled Digital Lending of Library Books (2018), https://doi.org/10.31228/osf.io/7fdyr (discussing the use of digital rights management (DRM) to prevent wholesale copying and distribution of materials scanned for controlled digital lending).

139. Michelle M. Wu, Building a Collaborative Digital Collection: A Necessary Evolution in Libraries, 103 LaW Libr. J. 527, 535, 2011 LAW Libr. J. 34, II 27.

140. An example of this is found in Maggie Wittlin, Lisa Larrimore Ouellette \& Gregory N. Mandel, What Causes Polarization on IP Policy, 52 U.C. Davis L. Rev. 1193, 1217 n.121 (2018) (authors cited to the codebook where the results of their research could be found and linked to Dataverse using a DOI).

141. Dataset + File Management, Dataverse Project, http:/guides.dataverse.org/en/latest/user/data set-management.html\# [https://perma.cc/9FQK-87Z2] ("When you restrict a file in Dataverse it cannot be downloaded unless permission has been granted."). 
could post information initially to preserve it and then wait until a later time to make it available for review. This could be beneficial if the researcher is trying to use the data or a document for a subsequent publication, or could be useful if there is a moratorium on the publication of the information based on the nature of the materials. There are already a few examples in Dataverse of authors using it for interviews, ${ }^{142}$ to which an author might want to restrict access until after publication. Authors who wish to make their research available post-publication can still post the data to a platform like Dataverse after the fact. ${ }^{143}$ Posting after publication does create more friction for finding the information, but it makes the information more readily available than simply letting it reside with the author.

I46 Past calls were made to post underlying materials kept "on file with" the author online. In the years since then, more resources and systems have been put in place to ensure that these materials can be uploaded for long-term preservation and access. While the technology is in place to make these materials available online, authors and journals must first consider the following issues.

\section{Issues to Consider}

\$47 Both Volokh and Alford noted some exceptions to making everything available online. ${ }^{144}$ While the following list is hardly exclusive, this article focuses on issues from three different perspectives, with special attention given to those unpublished materials that are listed under Rule 17 in the Bluebook. ${ }^{145}$ First, this article explores the main challenges imposed by copyright law related to unpublished materials. Second, this article discusses challenges that may be put in place by the author and the sources of the information, such as privacy and confidentiality. Finally, this article looks at the challenges imposed by the ever-changing nature of the technology that is used to preserve online materials. Taken together, these areas present both unique and overlapping challenges that authors, journals, and libraries must consider prior to developing a plan for posting materials online.

142. See Oliver Taherzadeh, Interview Transcripts, Harv. Dataverse (Oct. 25, 2016), https://doi .org/10.7910/DVN/4C9KFK; Valerie Flax, Food Log In-Depth Interviews, Harv. Dataverse (Sept. 30, 2020), https://doi.org/10.7910/DVN/SK6GWF; Vanessa Williamson, Transcripts of Read My Lips Interviews, Harv. DataVerse (Feb. 27, 2017), https://doi.org/10.7910/DVN/6WQIOY.

143. Lisa Larrimore Ouellette posted the data for the article "Do Patents Disclose Useful Information?" after its publication. See Lisa Larrimore Ouellette, Do Patents Disclose Useful Information?, 25 Harv. J.L. \& Tech. 545 (2012) (the article); Lisa Ouellette, Data for "Do Patents Disclose Useful Information?," Harv. Dataverse (Oct. 24, 2018), https://doi.org/10.7910/DVN/GOC0FV (the data).

144. Volokh, supra note 6 ("Naturally, there'll need to be some exceptions for sources that pose potential privacy or copyright problems (e.g., interviews with sources who were promised anonymity, or drafts of unpublished articles)."); Alford, supra note 9 ("Subject to confidentiality or similar concerns, there is no reason that most unpublished documents cited in law review articles are not accessible to readers.").

145. Bluebook, supra note 5, R.17.1-17.4, at 169-73. 


\section{Copyright}

I48 Copyright law poses significant challenges when it comes to posting unpublished manuscripts, working papers, dissertations and theses, and forthcoming publications online. These types of scholarly works may not be found online, and their copyright holders almost certainly are not the article authors. This means that article authors would be limited in the steps they could take in making these materials available through one of the solutions discussed above. ${ }^{146}$ While the source may very well be published in an accessible format in the future, either on an online repository or in print, future researchers might want access to the version used by the author.

I49 One way to address this would be to engage with the authors of the cited works to see whether they would make such sources available through their own institutional repository or a platform for posting working papers and preprints like SSRN. ${ }^{147}$ This would then allow the article author to cite these documents using a DOI or a persistent URL, and then also potentially use Perma.cc to capture the PDF version of the document in the web browser. One potential barrier to this could be where access to the preprint is restricted by the publisher. ${ }^{148}$ If the author of the cited work is not willing or able to post the entire unpublished work on the web for online linking and archiving, the article author could seek permission to engage in some limited scanning and posting of the cited materials to an online repository or provide mediated access to single users at a time without providing the ability to download or copy the materials.

I50 In cases where the author might be citing to older unpublished materials where the original author is not available to grant permission or the article author is not able to ascertain the actual author of the cited work, ${ }^{149}$ the author citing the work could potentially engage in the same limited scanning and posting of the cited materials, and

146. See supra section discussing tools and methods for preservation and access.

147. See SSRN, supra note 134.

148. While most publishers allow authors to post preprints, authors need to review their author's agreement to determine what version they are allowed to post. The Help Center on ResearchGate notes that "[s]ome publishers let authors share copies of their preprints without restrictions, while others allow it, but with limitations. Because publishers and journals differ on what they allow, you should always check your licensing agreement or publisher conditions before you share any of your work." Preprints, RESEARCHGATE, https://explore.researchgate.net/display/support/Preprints [https://perma.cc/X9EW-UK4P]. BonnieSwoger has noted that "[g]enerally speaking, publishers are more likely to be okay with authors posting copies of pre-print versus other manuscript versions. But each journal is different, and authors need to be aware of what they can do. The copyright transfer agreement is the best place to find this information." Bonnie Swoger, Understanding Your Rights: Pre-prints, Post-prints and Publisher Versions, ScI. Am. (Dec. 16, 2013), https://blogs.scientificamerican.com/information-culture/understanding-your-rights-pre-prints -post-prints-and-publisher-versions/ [https://perma.cc/J95R-B3DS]. Some publishers have detailed rules on their websites about what versions can be "self-archived" and when they can be posted to these platforms. For example, see Self-Archiving for Non-Open Access Books and Chapters, PALGRAVE, https://www.palgrave .com/gp/rights-permissions/our-policy-on-archiving-in-institutional-or-funding-body-reposit/6629030 [https://perma.cc/4GR5-NX5E]; Wiley's Self-Archiving Policy, WiLEY, https://authorservices.wiley.com /author-resources/Journal-Authors/licensing/self-archiving.html [https://perma.cc/B3AB-MVWF].

149. An example of this is grey literature. See generally Taryn L. Rucinski, The Elephant in the Room: Toward a Definition of Grey Legal Literature, 107 LaW Libr. J. 543, 2015 LaW Libr. J. 26 (providing an overview of grey literature and its application to legal resources). 
include along with the posting a notice that the author of the cited work can contact a designated party to request that the materials be taken down. ${ }^{150}$

I51 While these options may not solve every situation, they could be a step toward making more of these unpublished materials accessible to researchers.

\section{Privacy and Confidentiality}

\$52 In addition to copyright concerns, privacy and confidentiality issues can arise, especially related to email correspondences, letters and memorandums, and interviews.

I53 In terms of privacy, online posting of correspondences between parties, no matter the form, opens up the possibility that personal information might be shared with a wider audience. Email signatures, for example, commonly include email addresses, phone numbers, and physical addresses. Without redacting those details or restricting access in some way, anyone could access those means of personal identification. The same can be true with formal memorandums and letters exchanged between parties. In these situations, a possible solution might be to redact any personal information in the correspondences and post only information that researchers need to determine the authenticity of the document. Doing this would add to what some authors already do when they provide an explanatory parenthetical that includes either a direct quote from an email or letter or a summary of the information contained within the correspondence. ${ }^{151}$

I54 Confidentiality is a related issue that comes up when citing some correspondences and interviews. Here, an author could let the other parties know ahead of time that the communications will be posted online or made available as part of the publication of the article. Of course, parties may be less likely to participate if they know the information will be posted more widely, potentially creating a chilling effect on open exchanges with the researcher. Some authors specifically mention in their articles that they are providing anonymity or confidentiality for the interviewees to facilitate a "candid discussion." ${ }^{52}$ Redacting some information and masking the names of the participants could be a way to still post the bulk of the information online for future review while maintaining anonymity. Masking the names of email correspondents ${ }^{153}$ and

150. For an example of this type of notice, see the rights field for A Growing Concern: Protecting the Food Supply in an Era of Pharmaceutical and Industrial Crops, LeGAL Info. ArCHIVE, https://lipa.access .preservica.com/uncategorized/IO_f8251e57-6c15-422c-95fa-e20f0620dd77/ [https://perma.cc/82PM -JM58] ("This work may be protected by copyright. If you are a copyright owner who objects to the preservation of your work in this fashion, or if you believe that your copyright has been violated by the project's efforts, please contact the Legal Information Archive.").

151. For examples of where an author provides a summary of information contained within a letter and an email, see Kaufman, supra note 105, at 1840 nn.153-54.

152. See Diego A. Zambrano, The States' Interest in Federal Procedure, 70 StAN. L. Rev. 1805, 1822 n.84 (2018) (author states that "I granted the interviewees anonymity to facilitate candid discussion"); Abbe R. Gluck \& Nicole Huberfeld, What Is Federalism in Healthcare For, 70 Stan. L. Rev. 1689, 1701 n.29 (2018) (authors state that "[b]ecause many interviewees were sitting officials, or formerly sitting officials, we granted all of them confidentiality to allow for more candid discussion").

153. See Lisa Schultz Bressman \& Abbe R. Gluck, Statutory Interpretation from the Inside-An 
interviewees ${ }^{154}$ are steps that some authors have already taken when citing to these types of materials in articles. This same information could be redacted or masked in the full document so that future researchers would be able to review the bulk of the materials.

I55 While there would be drawbacks to redacted versions of the materials, they would provide at least some level of proof of the authenticity of the source and allow a future researcher to review the source from a fresh perspective. ${ }^{155}$ Moreover, redacting personally identifiable information or confidential information may allow for letters and email correspondences to be digitized and placed online, either through a publicly available platform, or in a manner that could more easily facilitate the transfer of these materials in a controlled manner.

\section{Ever-changing Technology and Long-Term Preservation}

I56 In addition to copyright, privacy, and confidentiality, another issue that must be addressed at the front end is how to take steps to ensure long-term preservation in light of ever-changing and evolving technology and preservation standards. In the case of materials in electronic formats, they are not "self-perpetuating" and therefore require a steward that will ensure that they are "actively backed up" and "consistently converted to current technologies." 156 Think of research from past decades that was kept on floppy disks. ${ }^{157}$ Without someone there to ensure the smooth transfer of these materials from one medium to another, most of the information would be inaccessible or lost to future researchers. The same can happen to materials posted online.

I57 While there are standards in place for online archives and digital repositories, ${ }^{158}$ many online repository platforms are propriety systems owned by commercial enterprises, meaning their long-term use is subject to the viability of the company and contract negotiations between the company and the subscribing institution. ${ }^{159}$ It is therefore

Empirical Study of Congressional Drafting, Delegation, and the Canons: Part II, 66 Stan. L. Rev. 725, 742 n.31 (2014) (footnote 31 is cited as "E-mail from confidential respondent to author (Oct. 14, 2013) (on file with authors)").

154. See James M. Anderson \& Paul Heaton, How Much Difference Does the Lawyer Make: The Effect of Defense Counsel on Murder Case Outcomes, 122 YALE L.J. 154, 161 n.17 (2012) (footnote 17 is cited as "Interview with Anonymous \# 1 (Mar. 3, 2011) (notes on file with authors).").

155. An example of an online repository of resources that includes a number of redacted documents is the Foreign Intelligence Law Collection at Georgetown University Law Center. See Foreign Intel. L. Collection, Geo. UnIv., https://repository.library.georgetown.edu/handle/10822/1052698 [https://perma .cc/4BXZ-4H9H].

156. Wu, supra note 23 , at $244, \mathbb{I} 37$.

157. NAT'L ACAD. Scis., supra note 1, at 96-97.

158. For a general overview of repository standards, see Ctr. Rsch. Librs., Trustworthy Repositories Audit \& Certification: Criteria and Checklist (2007), https://www.crl.edu/sites /default/files/d6/attachments/pages/trac_0.pdf [https://perma.cc/G6GK-323B]; see also Levels of Levels of Digital Preservation, Nat'L Digital Stewardship Alliance, https://ndsa.org/publications/levels-of -digital-preservation/ [https://perma.cc/HU4A-XCR9].

159. For general information on proprietary versus open source software, see Hillary Corbett et al., Choosing a Repository Platform: Open Source vs. Hosted Solutions, in Making Institutional RePOSITORIES Work (2016), https://scholarscompass.vcu.edu/libraries_pubs/33/ [https://perma.cc/WW9P 
imperative that someone has an exit strategy in place if the time comes that these materials need to be migrated to a new platform.

I58 Even with an exit strategy, it is rare that online repositories are able to maintain the same persistent link when moving from one platform to another. ${ }^{160}$ In instances where uploaded materials are migrated from one platform to another, any link that is included within a published article might be broken, even if the author intended for that link to be the one that would lead to the long-term landing page for the materials. For that reason, it may be prudent to not only encourage users to post materials on stable platforms but also provide a Perma.cc link to the document so that future readers have a "double back-up" of the source. ${ }^{161}$

\$59 To overcome limitations imposed by copyright, privacy, confidentiality, technology, and preservation standards, authors and journals should think about the steps they can take on the front end to make these materials more accessible to researchers. While no one perfect solution may work for all scenarios, certainly options are available to make more of these unpublished materials available online.

\section{Stewardship of Unpublished Materials}

I60 The final aspect to look at when analyzing how to make these unpublished materials more accessible is to examine who can ensure the long-term accessibility of these materials. To realize the full value of the research on a topic, these underlining documents must be "accessible to the community of researchers and others who might be able to use them."162 Simply scanning and uploading these materials to a webpage or storing them in a filing cabinet will not accomplish that goal. For true long-term accessibility to happen, reliable stewardship must be in place for these resources.

I61 In this part, this article defines what stewardship is and describes why it is essential to ensuring long-term accessibility of these materials. It then outlines the different parties that could play a role in serving as a reliable steward for these materials and explains the advantages and the disadvantages of these parties serving in this role from the perspective of a future researcher. This article then proposes a model

-ZYDT] (case study of two university libraries moving repository platforms); Ayla Stein \& Santi Thompson, Taking Control: Identifying Motivations for Migrating Library Digital Asset Management Systems, D-LiB MAG., Sept.-Oct. 2015, https://doi.org/10.1045/september2015-stein (discussing the results from a survey that analyzed reasons for libraries migrating from one system to another, with most moving to open source platforms).

160. This was the case when the materials in the former Chesapeake Project (now Legal Information Archive) were migrated from CONTENTdm to Preservica. See generally Caroline Hill, LIPA Signs as First Customer of New Preservica Consortia Offering, Legal TeCH. (Jan. 24, 2018), https:// legaltechnology.com/lipa-signs-as-first-customer-of-new-preservica-consortia-offering/ [https://perma .cc/KWB7-2R39] (announcement for the Legal Information Preservation Alliance becoming a customer of Preservica); Jesse Lambertson, Shucking Metadata for the Sake of Preservation: A Tiny Case Study of Dublin Core, 43 Tech. Servs. L. Libr. 14 (2018), (discussing the migration of metadata from Qualified Dublin Core (CONTENTdm) to Simple Dublin Core (Preservica)).

161. See supra notes $135-37$ and accompanying text.

162. NAT'L ACAD. SCIs., supra note 1, at 27, 95. 
that authors, journals, and libraries could implement to make these materials more accessible.

\section{Reliable Stewardship Ensures Accessibility}

I62 A truly accessible source-one readily available to future researchers upon request-is preserved for long-term use and is made available in a way that researchers can gain access to it. ${ }^{163}$ As already noted above, ${ }^{164}$ simply scanning and posting these materials on a website or storing them in repositories is not enough to ensure their long-term accessibility to researchers. Someone must also take steps to preserve these materials and add metadata so that future researchers will be able to access these materials. ${ }^{165}$ Metadata and appropriate finding tools will ensure that these materials can be "found easily, understood in context, and used appropriately"166

I63 In addition, stewardship requires someone who will curate and preserve these materials for as long as they remain useful for research or historical value. ${ }^{167}$ The steward must have the expertise and the time to account for format changes and move materials from one storage platform to another. ${ }^{168}$ For materials that are retained in print, stewards might look for ways to scan those materials-taking into account appropriate copyright, privacy, and confidentiality measures-to make them more accessible for researchers who are unable to view these materials in person.

I64 Regardless of material type, those responsible for maintaining these files need to take active and ongoing roles in ensuring materials are accessible. Such a form of stewardship treats these resources as "vital components of the research infrastructure."169

\section{Possible Stewards}

I65 When considering who could serve as stewards for these materials, three possibilities seem most likely, based on current practices among student-edited journals: original researchers or authors (e.g., on file with author), journals (e.g., on file with Harvard Law Review), or research institutions, which would include academic law libraries (e.g., on file with the Harvard Law School Library). ${ }^{170}$ Each of these parties has an interest in preserving these materials. For authors, access to these materials allows them to show that they are speaking with authority and accuracy. For journals, access to these materials demonstrates that they are publishing articles that are backed by sound research methods. For research institutions and libraries, access to these materials provides the fruit for future research endeavors and enhances their own stature within the academy.

163. Id. at $26-27$.

164. See supra section discussing tools and methods for preservation and access.

165. NAT'L ACAD. SCIS., supra note 1, at 27, 95.

166. Id. at 95 .

167. Id. at 27,95 .

168. Id. at $96-97$.

169. Id. at 27.

170. Id. at 109 . 
\$66 The duty to preserve and make these materials accessible cannot lie with only to one individual or entity. Authors have a duty to provide as much underlying research information to journals as possible, barring some of the issues already discussed above in part 2. ${ }^{171}$ Journals have a duty to hold authors accountable for providing this information and push back on authors who are less than forthcoming with these materials. Research institutions and libraries have a duty to ensure that infrastructure, such as stable platforms and partnerships, is in place to not only capture and preserve valuable research information using appropriate methods, but also to migrate to new platforms when necessary to prolong the life of these materials.

I67 Suitability for serving as a steward is analyzed here from two perspectives: (1) Does the party have the resources to both preserve these materials for long-term access and respond to future requests for access? (2) Does the party's mission align with preservation and access? Ultimately, the party best suited to serve as a reliable steward is the one whose mission focuses on preservation and access, and the one that has the expertise, know-how, and capability of providing long-term access to these materials.

\section{Authors and Original Researchers}

\$68 Since so many articles include citations to resources that are kept with authors, this group would seem like the easy choice to serve in this stewardship role. While authors should have the greatest stake in ensuring long-term access to their cited scholarly sources, they may not have a strong interest in taking on this task. ${ }^{172}$ At the end of an article or project, authors and researchers may move on to other projects with little interest in long-term preservation of the materials they used to complete their last project. ${ }^{173}$

I69 Entrusting preservation to authors or original researchers makes it more likely that these materials will be left unorganized, degrade over time or, worse, be discarded. ${ }^{174}$ Even with the best intentions, authors may simply not be equipped to ensure long-term preservation of materials because they lack the tools, the knowledge, or the time to implement best practices. A prime example of this is Roger Alford, who in writing his post about "on file with" materials took it upon himself to post source materials to a website instead of citing them as "on file with the author." ${ }^{175}$ In his 2008 article titled "Arbitrating Human Rights," Alford cited to three documents that he posted on his website. ${ }^{176}$ While Alford's efforts were laudable, his results provide an excellent example of why preservation is so important. As of October 2020, these documents were no longer accessible through the links provided in the article nor on the website they were

171. See supra section discussing issues to consider.

172. NAT'L ACAD. SCIS., supra note 1, at 99.

173. Id.

174. Id. at 96.

175. Alford, supra note 9.

176. See Roger P. Alford, Arbitrating Human Rights, 83 Notre Dame L. Rev. 505, 512 n.24, 513 n.25, 526 n.102 (2008) (the documents in question were the Declaration of Christopher Greenwood (footnote 24), the Declaration of James Crawford (footnote 25), and a Demand for Arbitration and Statement of Claim in the ChevronTexaco Corp. v. Emresa Estatal del Ecuador case (footnote 102)). 
posted on, Opinio Juris. ${ }^{177}$ This further demonstrates the need to ensure that materials are appropriately stored and cited to in journal articles.

I70 Taking aside the fact that authors would be tasked with the preservation of these materials, authors would also be on call to respond to individuals requesting access to these materials. Materials that are not made available online would need to be digitized or made available on demand. In addition, for those that are available online, authors would need to ensure continued maintenance of those materials or deal with issues that come with maintaining online resources, such as broken links or requests for materials that are in formats accessible for users with disabilities. Most authors would not have the time to process these requests, even if the total number of requests was small.

I71 One issue that may arise when authors do not serve as stewards for these materials is the particular author relinquishing control of them to another party. Letting go of these materials could be hard for some authors because of the connection they feel with the materials. With correspondences and interviews, authors may not want to give up materials that they have spent significant time developing and gathering. Authors may feel, based on their own expertise and authority, that they are the only parties who would be truly invested in ensuring the long-term care of these materials. In these situations, stewards may be able to work with authors to allow them to retain the originals of certain materials, while maintaining electronic versions that are stored for preservation and access purposes. Thus authors could retain these materials for their own use while also making them available for other researchers.

\section{Journals}

I72 As with authors, journals could be seen as candidates to serve as reliable stewards. Many sources that are cited as "on file with" are kept with the journals of publication. ${ }^{178}$ Moreover, like authors, journals do have a stake in ensuring long-term access to the underlying sources that are used to produce the scholarship that they publish.

173 While staff size has been mentioned when critiquing student-edited journals, ${ }^{179}$ the size of many student journals could provide them with the necessary staffing to both engage in large-scale preservation efforts and respond to post-publication requests for materials by future researchers. Because student-edited journals already perform a number of tasks and services for authors outside of what is provided by peer-reviewed journals, one could argue this is an additional service that they could take on that has the potential to provide additional value to legal scholarship. ${ }^{180}$

177. While these are case file materials that could be found through alternative sources, this requires additional work on the part of the researcher after discovering that the documents are no longer available on the author's website.

178. See supra tbl. 1.

179. See Richard A. Posner, Law Reviews, 46 Washburn L.J. 155, 156-57 (2006) ("The author, indeed, is likely to suffer, because the student editors, having a great deal of time to devote to each article because law journal staffs are so large, often torment the author with stylistic revisions.").

180. See id. at 156 ("The size of law review staffs enables them not only to check the author's citations but also to make many substantive comments and also engage in line-by-line copyediting."); Mermin, supra note 27, at 609 (outlining the five labors that students perform, including tracking down omitted 
I74 Through their own recommendations, both Volokh and Alford inferred that journals or a consortium of journals could develop a platform for uploading and preserving content that is often kept "on file with" the author. ${ }^{181}$ As journals transition to more digital first publishing, this type of preservation of materials might integrate well with the changing nature of journal publishing. Journals that already publish on institutional repositories could use these same platforms to post these materials for future access. While there are benefits to allowing journals to take this on, there are several risks with entrusting them with the type of stewardship that is needed for these materials.

I75 One of the main risks with entrusting student-edited journals with taking on sole stewardship over these materials is the nature of how student-edited journals are staffed. Student editorial boards turn over every year, ${ }^{182}$ which can lead to a lack of continuity and information sharing - both critical to ensuring that these materials are preserved for an appropriate length of time. Without proper administrative support and transition procedures in place, there is a risk that information will not be passed down between the editorial boards. This could cause numerous issues, with the worst being that materials are lost before being properly filed away. In addition, without having a defined set of procedures for dealing with requests for materials, there could be discrepancies in the journal's handling of these requests. The lack of consistency could lead to either rejecting legitimate requests from researchers or providing access to materials that may be protected by copyright or an agreement that restricts how someone can access the materials.

I76 In addition to a lack of continuity, student-edited journals are not experts in long-term preservation methods. While more journals are moving their publications to institutional repositories, ${ }^{183}$ long-term preservation has not been the major driver of this movement. Instead, the call for open access publishing led to the push to publish journals online. ${ }^{184}$ Many journals have historically left the long-term preservation of their own published articles to vendors for online access and law libraries for print access. ${ }^{185}$

I77 While journals may very well have a strong interest in ensuring that unpublished materials are retained and made accessible, they may not be best suited to serve as stewards for these materials because of their turnover and inexperience with longterm preservation needs and mechanisms.

citations and correcting citation forms).

181. Volokh, supra note 6 ("To solve that problem, law reviews might put together a consortium that would store all the items using URLs that are sure not to change (e.g., http://lawreview.org /yalelj/107/2431/sourcename.pdf)."); Alford, supra note 9 ("As a matter of course every law journal should eliminate as many "On File With Author" references and replace them with uploaded documents available to its readers with the new reference.").

182. See Wise et al., supra note 16, at 9; Keele \& Pearse, supra note 4, at 403, II 48; Stracher, supra note 12, at 363, 365; Day, supra note 26, at 573.

183. Law Schools, supra note 131.

184. See Beatty, supra note 111, at 581, II 25; see also Donovan \& Watson, supra note 2, at 554, II 2.

185. Keele \& Pearse, supra note 4, at 390, II 20. 


\section{Research Institutions and Libraries}

I78 Research institutions also have a stake in ensuring the long-term accessibility of these materials and could fill the stewardship role through their libraries. Maintaining long-term access to underlying research supports the credability of scholarship, which could further boost the reputation of the institution. Libraries are best positioned to take the lead on institutional stewardship because of their general purpose, mission, and noncommercial nature; their experience with long-term preservation tools and challenges; their staffing models; and their ability to navigate issues related to posting these types of materials online. All of these qualities enable law libraries to meet the requirements of knowing how to preserve these materials and to respond to future requests for access.

179 The very nature of libraries and their mission make them an ideal candidate to serve as stewards of these materials. As Michelle Wu has previously stated, "The core purpose of an academic law library is to serve the needs not only of today's users but also tomorrow's." 186 In doing such, libraries have always sought to preserve materials for "future users," even at times when the very publishers of those materials were not expected to maintain a "permanent back stock of their publications." 187 If journals are not equipped to serve in this stewardship role, then it is incumbent upon law libraries to step in and take on this responsibility. Unlike private enterprises that have to factor in profits and the commercial value of maintaining these resources, law libraries are able to focus on the long-term needs of researchers. ${ }^{188}$

I80 In addition, law libraries already possess the necessary expertise with the tools required to preserve and make these materials accessible through online platforms. Law libraries are keenly aware of the dangers imposed by link rot and the fleeting lifespan of resources that are posted on websites. ${ }^{189}$ In addition, libraries have taken the lead on developing, supporting, and promoting institutional repositories. ${ }^{190}$ In doing so, law libraries have provided platforms not just for student-edited open access journal publications ${ }^{191}$ but also for researchers to use to post materials and to cite using "consistently

186. Wu, supra note 23 , at 235 , II 5.

187. Danner, Leong \& Miller, supra note 3, at 46, II 24.

188. Wu, supra note 139 , at 544-45, III 60-62.

189. See generally Lyons, supra note 4 (a study of the prevalence of broken links and the need for citing to persistent identifiers of electronic documents); Keele \& Pearse, supra note 4, at 391-93, II 27-30 (as part of a series of recommendations for how librarians can support student journals, the authors dedicate a section to preventing link rot).

190. See Carol A. Parker, Institutional Repositories and the Principle of Open Access: Changing the Way We Think about Legal Scholarship, 37 N.M. L. Rev. 431 (2007); James M. Donovan \& Carol A. Watson, Will an Institutional Repository Hurt My SSRN Ranking: Calming the Faculty Fear, AALL SPECTRUM, Apr. 2012, at 12; David Brian Holt \& Erik Beck, Rethinking the Scholarly Legal Publishing Life Cycle, AALL Spectrum, May/June 2020, at 44; see also NAT'L AcAD. Scis., supra note 1, at 103 ("Many repository efforts are led by university libraries, which have begun exploring the new issues posed by research data and other digital information as increasingly central components of the scholarly record.").

191. Brown, supra note 130 , at 21. 
designed" links that are "less likely to change than URLs for academic or commercially hosted web sites." 192

I81 Law libraries are also well placed to take on this role because of the continuous stewardship that they can provide compared to student-edited journals. The turnover of student editorial boards makes it unlikely that they would be able to effectively ensure that materials are made available at the outset and over the long term. To ensure that materials are available for long-term use, those serving as stewards must be prepared to deal with format changes and new technologies. ${ }^{193}$ Law libraries do not experience the same level of turnover as student-edited journals and, as organizations that are built to preserve materials, have an interest in ensuring that steps are taken to facilitate knowledge transfer between departing and incoming employees. This continuity would further minimize issues from not properly backing up resources and transitioning them to new systems. ${ }^{194}$

I82 Unlike journals and authors, law libraries are also best positioned to work through issues that come with potentially posting these materials online, most notably embargoes and copyright issues. Many sources that are kept "on file with" authors or journals may very well need to be embargoed for a period of time for privacy protections or to ensure that authors can benefit from their work. Some law libraries are adept at navigating these types of issues because they already deal with them on a regular basis related to special collections and archival materials. Librarians would be able to help student-edited journals navigate the complexities that surround publishing articles that contain references to embargoed sources and ensure that these materials are available at the end of the embargo period. Similar to how they handle other embargoed materials, librarians could provide a landing page that includes information about the source, and then provide the full source on the same page at the end of the embargo period. ${ }^{195}$

I83 Additionally, librarians are equipped to work through the copyright issues that could arise with providing online access to these materials. ${ }^{196}$ Many common "on file with" materials present issues in terms of making them available online, such as unpublished manuscripts, working papers, dissertations, and theses. The questions of whether something can be digitized, whether it can be posted online for broader consumption, and what type of controlled access or digital rights management might be needed are all questions that librarians are better equipped to address than individual authors and

192. Keele \& Pearse, supra note 4 , at 392-93, II 30.

193. Wu, supra note 23 , at 241-42, III 26-28.

194. Volokh, supra note 6.

195. Georgetown Law Library embargos S.J.D. dissertations for three years before posting them on its institutional repository. Prior to posting a dissertation, the library creates a landing page for the dissertation in the repository that includes the name of the author, the subjects covered, and the abstract for the dissertation. For an example of a landing page for a dissertation that was not posted at the time of the drafting of this article, see Andrew Jensen Kerr, Essays on Culture, Art, and Authority (2020) (S.J.D. dissertation, Georgetown University Law Center), http://hdl.handle.net/10822/1061131 [https://perma.cc /S7CC-9R94].

196. Keele \& Pearse, supra note 4 , at 402-03, II 47. 
journals. Moreover, law libraries can address situations where rights holders act through takedown notices.

I84 Even though law libraries are best placed to serve in this stewardship role, one has to wonder how they can take it on given the complexities of managing this on top of what continues to be a growing list of changing expectations, new responsibilities, and shrinking budgets and staff. ${ }^{197}$ Providing this type of support for journals and authors could be a long-term growth area for law libraries. As more materials are published online, law libraries could pivot from supporting print materials and electronic databases to becoming active partners in the publication process.

I85 The question that still remains is how preserving formerly "on file with" the author materials would work in practice.

\section{Model for Ensuring Long-Term Accessibility}

\$86 Having libraries serve as stewards for unpublished materials previously held "on file with" the author is easier said than done. How this could be implemented raises several questions about the range of resources and expertise among academic law libraries. Some libraries are better suited to take on this role because of their previous experience with special collections, archives, and digitization. This raises the question, then, of whether the library of the author or the library of the journal should serve as the steward of these materials. Without clear guidance, libraries could end up duplicating efforts or, worse, find themselves in a situation where no one takes responsibility. Without a clear path forward, authors, journals, and libraries may develop their own standards and workflows, which could ultimately lead to materials falling through the cracks. To get on the same page, authors, journals, and libraries must work together.

I87 Regardless of whose library serves in this stewardship role, authors and journals must commit to a new set of expectations when it comes to citing to unpublished materials. First, authors must adhere to the principle that research should be as open as possible. This requires efforts on the front end, such as communicating with interviewees or authors of unpublished materials, to ensure that as much information as possible can be captured, preserved, and made accessible prior to publication. Second, all law journals must serve as gatekeepers and enforce standards similar to those used by journals with articles that include empirical research data. ${ }^{198}$ Journals should engage with authors during the editorial process to determine what steps can be taken to make "on file with" materials accessible. Journals could initially discuss such issues as copyright and privacy with librarians at their institutions, better positioning them to provide

197. See generally Taylor Fitchett et al., Law Library Budgets in Hard Times, 103 Law Libr. J. 91, 2011 Law Libr. J. 5 (discussing library budgets in the post financial crisis); Ursual Gorham \& Paul T. Jaeger, The Law School Library or the Library at the Law School: How Lessons from Other Types of Libraries Can Inform the Evolution of the Academic Law Library in the Digital Age, 109 LAW Libr. J. 51, 2017 LAW Libr. J. 2 (discussing the challenges that libraries face, including budget and staffing cuts); Lynne F. Maxwell, The Emperor's New Law Library: The Decline and Fall of Academic Law Libraries or a New Chapter, 44 RutgERS L. REc. 46 (2016-2017) (discussing library budgets, staffing, and new services).

198. See supra notes 119-27 and accompanying text. 
authors with suitable options early in the process. Both authors and journals taking these steps improve the chances that materials will be available for preservation and made accessible prior to the publication of an article. The only remaining piece is how to capture and preserve these materials in a way that will lead to long-term accessibility by future researchers.

\$88 When determining which library will serve the stewardship role, there are clear advantages and disadvantages for either the library of the author or the library of the journal. First, the library of the author has the advantage of already working quite closely with the author during the research process. This would allow the library to engage with the author at the beginning of the process and to provide options for making the materials accessible prior to the submission of the article for publication. Second, depending on the level of research support the library provides to the author, library staff may have already digitized the materials during the research process, shortening the efforts needed to post these materials online. Third, where the author writes on similar topics, the library has the ability to connect materials from multiple papers, potentially building a more useful database for researchers. Finally, if the author does hold onto the original unpublished materials, it would be easier for the library to engage with the author if for some reason duplicates or electronic versions were somehow lost or destroyed.

I89 While relying on the library of the author has its advantages, it also has several critical disadvantages. First, given how long it takes for articles to be published, it is possible for an author to move during the writing of the article or the publication of it. This could create confusion over which library would be expected to support preservation and accessibility efforts. Second, not all journal article authors come from academic institutions that are supported by a law library. Law journal articles are written by a variety of authors, including practitioners and judges. Finally, as already stated, not all institutions possess the in-house expertise to support the authors, nor do they have the resources to maintain such files.

\90 The library of the journal also presents several advantages and disadvantages. The first advantage is the strong relationship between the library and the journal. The library could provide a process by which the journal can preserve and maintain materials for future reference, similar to the service offered by Harvard Law. ${ }^{199}$ Second, by working with its home library, an individual journal would be able to follow a consistent set of practices, so frequent readers of the same publication would become familiar with how to locate materials cited within these journals. Third, because of the close relationship between the journal and its home library, the journal would be better placed to not only navigate content migration but also add in features to its publications such that readers are notified of new ways to access content previously cited in an individual journal article. ${ }^{200}$ Finally, if all journals adopted the same approach, then duplication would be limited, as the repository would be clear in every circumstance.

199. See supra notes 93-99 and accompanying text.

200. Similar to Volokh's proposal to put "an author's correction on a separate web page" to create 
T91 In spite of the advantages of relying on the library of the journal, there are some notable disadvantages. First, relying on the library of the journal could mean missing materials with certain restrictions because the library was not engaged at the front end of the research process. Second, as with library of the author, the library of the journal may also lack the resources and expertise to perform the necessary stewardship functions.

192 With no perfect solution in sight, what could be a possible third approach that would ensure that these materials are preserved without having to worry about the expertise and resources of the individual libraries? As already stated, authors and their home libraries must work together at the beginning of the research process to address copyright, privacy, and confidentiality issues. Moreover, journals have to serve as gatekeepers and hold authors to a higher standard, as well as work with their home libraries to identify solutions that can be employed to capture unpublished materials, preserve them in stable platforms, and make them available to readers and researchers by including citations that point to online formats. No matter the solutions that libraries put in place, the success of making these materials available hinges on the initial efforts of authors and journals.

193 For this to be successful, libraries must work together to adopt solutions and practices that all libraries can use, regardless of their expertise and resources. To do this, libraries need to either create a shared repository for posting unpublished materials or identify stable, nonprofit platforms that can be utilized for posting unpublished materials that will appear in law journal articles. If unable to develop their own shared platform, law libraries could provide financial support for existing platforms and work together to provide centralized training for librarians on how to best utilize these platforms. Librarians could also develop a set of best practices that would include not just posting materials to stable platforms, like Dataverse, but also backing up these materials through Perma.cc. Together, this set of practices could meet the ideals that Volokh recommended when he imagined that "law reviews might put together a consortium that would store all the items using URLs that are sure not to change."201 Instead of law reviews forming a consortium to store these materials, it would be libraries coming together to develop consistent practices that can be utilized across the board. With consistent practices in place, libraries will be able to more easily monitor resources and determine when steps should be taken to migrate them to new platforms.

194 The ultimate goal is to ensure that more underlying materials are added to established online repositories or platforms prior to the publication of an article so that consistent links are provided at the time of publication. In taking on these initiatives,

a "pocket part"-like service for articles, student-edited journals that publish articles on a journal-hosted website or institutional repository could include links on the landing page to where researchers can find cited content that was either held on file with the author at the time of publication or migrated to a new platform since publication (e.g., migrated from author hosted website to Dataverse). See Volokh, supra note 6 (section titled "Allowing Corrections or Updates of Articles").

201. Id. 
libraries will be able to step in and support long-term preservation for materials that until now were destined to be lost, misplaced or, worse, destroyed.

\section{Conclusion}

195 Legal scholarship's potential impact on society requires authors, journals, and libraries to take steps to make articles and the underlying sources within them more accessible for readers and future researchers. Significant steps have been taken over the past decade to make articles more widely available through online repositories. Moreover, improvements have been made to ensure that online resources cited within articles are accessible through the use of web archiving tools and persistent links. The last step to fully unlocking legal scholarship is to make more unpublished materials that have been traditionally held "on file with" the author available through stable online platforms that are maintained by reliable stewards. To do this, authors, journals, and libraries must work together through all phases of the scholarship production processresearch, editing, and publication-to ensure that unpublished materials are captured, preserved, and made available for all who wish to learn from them. By allowing future researchers seamless access to these underlying sources, they will be able to test the author's assessment, draw their own conclusion, and build on the work of past legal scholars. 